\title{
Regulation of Structural Plasticity by Different Channel Types in Rod and Cone Photoreceptors
}

\author{
Nan Zhang and Ellen Townes-Anderson \\ Department of Neurosciences, University of Medicine and Dentistry of New Jersey-New Jersey Medical School, Newark, \\ New Jersey 07103-2714
}

In response to retinal disease and injury, the axon terminals of rod photoreceptors demonstrate dramatic structural plasticity, including axonal retraction, neurite extension, and the development of presynaptic varicosities. Cone cell terminals, however, are relatively inactive. Similar events are observed in primary cultures of salamander photoreceptors. To investigate the mechanisms underlying these disparate presynaptic responses, antagonists to voltage-gated L-type and cGMP-gated channels, known to be present on rod and cone cell terminals, respectively, were used to block calcium influx during critical periods of plasticity in vitro. In rod cells, L-type channel antagonists nicardipine and verapamil inhibited not only the outgrowth of processes and the formation of varicosities, but also the synthesis of vesicle proteins, SV2 and synaptophysin. In contrast, the synthesis of opsin in rod cells was unaffected. In cone cells, L-type channel antagonists caused only modest changes. However, cobalt bromide, which blocks all calcium channels, and L-cis-diltiazem, a potent antagonist of cGMP-gated channels, significantly inhibited varicosity formation and synthesis of SV2 in cone cells. Moreover, the cGMP-gated channel agonist 8-bromo-cGMP caused a significant increase in varicosity formation by cone but not rod cells. Thus voltage-gated L-type channels in rod cells and cGMP-gated channels in cone cells are the primary calcium channels required for structural plasticity and the accompanying upregulation of synaptic vesicle synthesis. The differing responses of rod and cone terminals to injury and disease may be determined by these differences in the regulation of $\mathrm{Ca}^{2+}$ influx.

Key words: cone; rod; neuritic process; varicosity; synaptic vesicle proteins; L-type calcium channel; cGMP-gated channel
In response to injury and insult, adult CNS neurons display varying degrees of regeneration and reactive plasticity. Responses range from olfactory neurons that regenerate completely from stem cells after axotomy of the olfactory nerve (Harding et al., 1977), to afferent fibers for the septal nuclei that are able to produce limited sprouting after denervation of septal neurons (Raisman 1969), to thalamic neurons that seem unable to recover from an axonal lesion even in the presence of a peripheral nerve graft (Benfey et al., 1985). In the amphibian CNS as well, some neurons regenerate axons easily, whereas others display no regenerative potential (Lyon and Stelzner, 1987). Understanding the cause for these differences holds the promise of increasing our knowledge of the basic mechanisms of regeneration in the CNS.

In the retina, recent descriptions of human and animal models of retinitis pigmentosa (RP) and retinal detachment have illustrated that even cells that have generally similar functions, the cone and rod photoreceptors, can have differing responses to injury. In a cat model of retinal detachment, rod cell axons retract toward their cell bodies, whereas cone cells are relatively unaffected (Erickson et al., 1983; Lewis et al., 1998). In human autosomal dominant RP, rod cells extend long neurites toward the inner retina. Along these neurites, varicosities filled with synaptic vesicles are formed. Cone cell terminals, in contrast,

\footnotetext{
Received Jan. 8, 2002; revised April 12, 2002; accepted May 7, 2002.

This study was supported by National Institutes of Health Grant EY12031 and by the Coalition for Brain Injury Research. We thank Dr. John Reeves (Department of Pharmacology and Physiology, University of Medicine and Dentistry of New Jersey) for critical reading of this manuscript.

Correspondence should be addressed to Dr. Ellen Townes-Anderson, Department of Neurosciences, University of Medicine and Dentistry of New Jersey, 185 South Orange Avenue, Newark, NJ 07103-2714. E-mail: andersel@umdnj.edu. Copyright (C) 2002 Society for Neuroscience $0270-6474 / 02 / 227065-15 \$ 15.00 / 0$
}

show little change (Li et al., 1995; Milam et al., 1996). Feline rod/cone dysplasia also exhibits rod neurite extension into the inner retina (Chong et al., 1999). In mouse models of retinal degeneration known as $r d$ or $r d s$ and in light-induced degeneration, rod cell terminals have been shown to expand as adjacent rod photoreceptors die (Jansen and Sanyal, 1984, 1987, 1992). In a pig model of an autosomal dominant RP, rod cells have short sprouts emanating from their synaptic spherules, whereas cone synaptic pedicles remain relatively inert, although they are able to make new synaptic connections with rod bipolar cells ( $\mathrm{Li}$ et al., 1998; Peng et al., 2000). The stimuli for and the mechanisms of structural plasticity in the case of rod cells, and structural stability in the case of cones, are unknown.

Primary cultures of salamander rod and cone photoreceptors show many of the features of axonal and terminal plasticity seen in vivo. Rod cells retract their axons shortly after cell plating, then extend neurites, and finally form varicosities filled with synaptic vesicles. Cone cells will also extend neurites and form varicosities; however, the number of neurites and varicosities is consistently lower in cone than in rod cells (Mandell et al., 1993). Recent studies using the L-type calcium channel antagonist nicardipine showed that blocking calcium influx during and immediately after retinal dissociation prevented rod axonal retraction, whereas continued application of nicardipine reduced process outgrowth (Nachman-Clewner and Townes-Anderson, 1999). There is growing evidence that distinct calcium channels exist in cone and rod cells: physiological evidence has been found that $\mathrm{Ca}^{2+}$ influx occurs through cGMP-gated channels at the axonal terminals of cone but not rod cells (Rieke and Schwartz, 1994; Savchenko et al., 1997). Immunocytochemical examination has demonstrated that the $\alpha$-subunits of L-type calcium channels present in rod and 
cone terminals differ in density. A large aggregation of L-type channels exists at the synaptic active zone of rod cells, whereas channel distribution is diffuse in cone cells (Nachman-Clewner and Townes-Anderson, 1999; Morgans, 2001). Finally, L-type calcium channels in cone and rod cells possess distinct physiological characteristics (Wilkinson and Barnes, 1996; Kourennyi and Barnes, 2000). We have hypothesized therefore that the functional type of synaptic calcium channel may determine the kind of plasticity displayed in response to nerve cell injury. Using antagonists to L-type and cGMP-gated channels, we present evidence here that structural plasticity and regenerative growth in vitro are controlled primarily by L-type channels in the rod photoreceptor and by cGMP-gated channels in the cone photoreceptor.

Preliminary findings of this work have been presented previously in abstract form (Zhang and Townes-Anderson, 2000, 2001).

\section{MATERIALS AND METHODS}

Antibodies, probes, and chemicals. Mouse monoclonal antibody to the synaptic vesicle glycoprotein SV2 (Buckley and Kelly, 1985) was a generous gift of Dr. K. Buckley (Harvard Medical School, Cambridge, MA). Rabbit polyclonal antibody to synaptophysin (p38) (Valtorta et al., 1988), an integral synaptic vesicle membrane protein, was a generous gift of Dr. F. Valtorta (S. Raffaele Scientific Institute, Milan, Italy). Anti-opsin monoclonal antibody 4D2 was a gift of Dr. R. Molday (University of British Columbia, Vancouver, Canada); 4D2 is specific for the opsin of M(red) rod photoreceptors (Hicks and Molday, 1986). Rabbit polyclonal antibody to rab6 [C19, a marker protein of trans-Golgi networks (TGNs)] (Goud et al., 1990; Antony et al., 1992; Deretic and Papermaster, 1993) was purchased from Santa Cruz Biotechnology (Santa Cruz, CA). The specificity of SV2, p38, 4D2, and rab6 antibodies has been demonstrated in the salamander retina (Mandell et al., 1993; Nachman-Clewner and Townes-Anderson, 1996). Goat anti-mouse IgG antibody for culture dish coating was purchased from Boehringer Mannheim Corporation (Indianapolis, IN). Sal-1 mouse hybridoma supernatant was generously provided by Dr. P. MacLeish (Morehouse School of Medicine, Atlanta, GA). All immunolabeling reagents including goat anti-mouse rhodamine antibody, goat anti-mouse-isothiocyanate (FITC) antibody, goat anti-rabbit rhodamine antibody, and goat anti-rabbit-FITC antibody were purchased from Boehringer Mannheim. Papain was purchased from Worthington Biochemical Corporation (Lakewood, NJ). Nicardipine (Nc), verapamil (Vrp), L-cis-diltiazem (Lcd), 8-bromo-cGMP (8Br-cGMP), and dimethyl sulfoxide (DMSO) were purchased from Sigma (St. Louis, MO). Cobalt bromide $(\mathrm{CoBr})$ was purchased from Fisher Scientific (Pittsburgh, PA). Channel antagonists and agonists were prepared as stock solutions and frozen at $-20^{\circ} \mathrm{C}$ before application. Nc was dissolved in $100 \%$ DMSO at a concentration of $10 \mathrm{mM}$; Vrp, Lcd, 8Br-cGMP, and CoBr were dissolved in $\mathrm{dH}_{2} \mathrm{O}$ at concentrations of 5, 100, 22, and $100 \mathrm{~mm}$, respectively.

Isolation and culture of photoreceptors. Retinas were obtained from light-adapted adult tiger salamanders (Ambystoma tigrinum, $16-30 \mathrm{~cm}$ in length; Charles Sullivan Inc., Nashville, TN) that were decapitated and pithed according to protocols approved by the Institutional Animal Care and Use Committee at the University of Medicine and Dentistry of New Jersey and in strict accordance with the Policy on the Use of Animals in Neuroscience Research of the Society for Neuroscience and guidelines from the National Institutes of Health. Dissociation of the retina was performed as described previously using enzymatic digestion with papain and trituration (MacLeish and Townes-Anderson, 1988; Mandell et al., 1993). Briefly, retinas were dissected at room temperature $\left(20-22^{\circ} \mathrm{C}\right)$ in room light, incubated for 45 min on a shaker in enzyme Ringer's solution containing $14 \mathrm{U} / \mathrm{ml}$ papain, $85 \mathrm{~mm} \mathrm{NaCl}, 1.5 \mathrm{~mm} \mathrm{KCl}, 25 \mathrm{~mm} \mathrm{NaHCO}_{3}$, $0.5 \mathrm{mM} \mathrm{CaCl}_{2}, 0.5 \mathrm{mM} \mathrm{NaH}_{2} \mathrm{PO}_{4}, 24 \mathrm{~mm}$ glucose, $0.03 \mathrm{~mm}$ phenol red, 1.0 $\mathrm{mM}$ sodium pyruvate, and $2.7 \mathrm{~mm}$ DL-cysteine. Retinas were gently triturated with a 3-mm-diameter wide-bore pipette 25 times to obtain a cell suspension containing predominantly photoreceptor cells. Cells were plated onto acid-cleaned glass coverslips coated with goat anti-mouse IgG antibody and the Sal-1 antibody (MacLeish et al., 1983). Cells were grown in a serum-free defined medium containing (in $\mathrm{mM}$ ): $108 \mathrm{NaCl}, 2.5$ $\mathrm{KCl}, 2 \mathrm{HEPES}, 1 \mathrm{NaHCO}_{3}, 0.5 \mathrm{NaH}_{2} \mathrm{PO}_{4}, 1$ sodium pyruvate, $0.5 \mathrm{MgCl}_{2}$, 24 glucose, $1.8 \mathrm{CaCl}_{2}, 7 \%$ medium $199,1 \times$ minimum essential (MEM) vitamin mix, $0.1 \times$ MEM essential amino acids, $0.1 \times$ MEM nonessential amino acids, 2 glutamine, $2 \mu \mathrm{g} / \mathrm{ml}$ bovine insulin, $1 \mu \mathrm{g} / \mathrm{ml}$ transferrin, 5 taurine, $0.8 \mu \mathrm{g} / \mathrm{ml}$ thyroxine, $10 \mu \mathrm{g} / \mathrm{ml}$ gentamycin, and $1.0 \mathrm{mg} / \mathrm{ml}$ bovine serum albumin. Cells were maintained in a humidified chamber at $10^{\circ} \mathrm{C}$ in the dark.

Immunocytochemistry of cultured photoreceptors. Photoreceptors were fixed with $4 \%$ paraformaldehyde in $0.125 \mathrm{M}$ phosphate buffer, $\mathrm{pH} 7.4$, for at least $24 \mathrm{hr}$ at $4^{\circ} \mathrm{C}$ and labeled by the following procedure. (1) Cells were washed with PBS ( $450 \mathrm{~mm} \mathrm{NaCl}, 20 \mathrm{~mm}$ sodium phosphate buffer, $\mathrm{pH}$ 7.4) three times at room temperature. (2) Cells were incubated for 1 $\mathrm{hr}$ at room temperature in goat serum dilution buffer (GSDB; 16\% normal goat serum, $450 \mathrm{~mm} \mathrm{NaCl}, 0.1 \%$ Triton X-100, $20 \mathrm{~mm}$ phosphate buffer, $\mathrm{pH}$ 7.4) to block nonspecific binding and permeabilize the plasma membrane. (3) Cells were incubated with primary antibodies dissolved in GSDB at $4^{\circ} \mathrm{C}$ overnight. 4D2 antibody was used at a dilution of 1:25; SV2 and synaptophysin antibodies were used at dilutions of 1:20 and 1:500, respectively; and rab6 antibody was used at a dilution of 1:50. For negative controls, no primary antibodies were added to the GSDB at this step. (4) Cells were rinsed with wash buffer ( $450 \mathrm{~mm} \mathrm{NaCl}, 0.3 \%$ Triton $\mathrm{X}-100$, and $20 \mathrm{~mm}$ phosphate buffer) three times followed by a rinse with PBS. (5) Cells were incubated with Triton-free GSDB $(450 \mathrm{~mm} \mathrm{NaCl}$, $16 \%$ normal goat serum, and $20 \mathrm{~mm}$ phosphate buffer) for $1 \mathrm{hr}$ at room temperature. (6) Cells were incubated with secondary antibodies conjugated with fluorescence labels rhodamine or FITC for $50 \mathrm{~min}$ at room temperature in the dark. Secondary antibodies were used at a dilution of 1:35 and dissolved in Triton-free GSDB. (7) Cells were washed with PBS three times followed by a final rinse with $5 \mathrm{~mm}$ phosphate buffer, $\mathrm{pH} 7.4$, at room temperature. (8) Cells were mounted in anti-fade medium containing $90 \%$ glycerol, $10 \%$ PBS, including $2.5 \%$ (w/v) 1,4-diazobicyclo[2,2,2]octane to prevent bleaching of immunofluorescence. For double labeling, the two primary antibodies or two secondary antibodies were diluted together in GSDB buffer and applied to cells simultaneously.

Quantification of cell outgrowth. For cell identification, see Data analysis. For the analysis of process outgrowth and formation of varicosities, cone cells were viewed with conventional phase-contrast microscopy, and 4D2-stained rod cells were viewed with UV light microscopy on an inverted photomicroscope equipped for FITC and rhodamine epifluorescence. In some experiments, cone cells were also viewed with UV light microscopy based on immunofluorescent staining of vesicle proteins. Computer images of cells were captured by a CCD camera and analyzed with NIH image software (V.1.44). Any outgrowth extending $>5 \mu \mathrm{m}$ from the soma was considered to be a process. A process was defined as a $1^{\circ}$ process before it branched, a $2^{\circ}$ process after branching, or a $3^{\circ}$ process after further branching. Primary processes were further

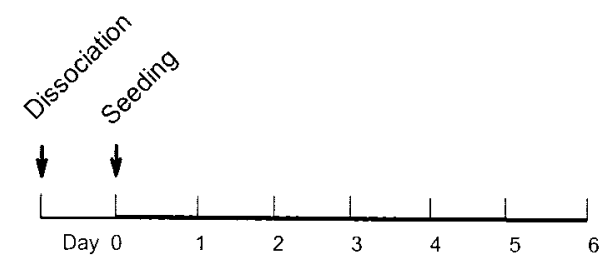

Days in Culture

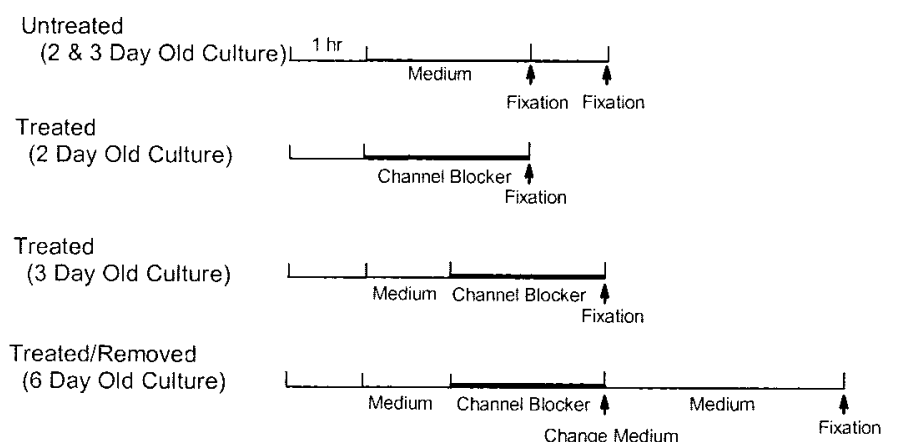

Figure 1. Experimental design for administration of channel blockers. Photoreceptors were cultured with channel blockers for $48 \mathrm{hr}$ after seeding or after $1 \mathrm{~d}$ in culture. Some photoreceptors were cultured for an additional $3 \mathrm{~d}$ after channel blockers were removed from the culture medium. 
divided into thick, thin, and lamellipodial-like processes. A varicosity was defined as a swelling along a neuritic process with a diameter $>0.5 \mu \mathrm{m}$.

Densitometry analysis. Photoreceptors were double stained with 4D2 and synaptophysin antibodies and imaged with confocal microscopy. Briefly, an LSM410 microscope, equipped with an argon/krypton laser and a $63 \times, 1.4$ numerical aperture oil immersion objective (Carl Zeiss, Oberkochen, Germany) was set to scan $1 \mu \mathrm{m}$ optical sections of photoreceptors. A $488 \mathrm{~nm}$ excitation filter and a 515-540 nm narrow bandpass emission filter were used for FITC, and a $568 \mathrm{~nm}$ excitation filter and a $590 \mathrm{~nm}$ long-pass emission filter were used for rhodamine. Because synaptophysin staining levels in cone cells have been shown to be significantly higher than in rod cells (Townes-Anderson and NachmanClewner, 2001), confocal sensitivity and contrast parameters were set separately for cone and rod cells identified by 4D2 staining to ensure that staining intensities of captured images were in the linear range for cones and rods, respectively. The optical sections were scanned at two levels: one level was close to the culture substrate to show processes and varicosities, and another level was distant from culture substrate to show intracellular structures including TGNs. Synaptophysin staining was analyzed with the "density slice" function of NIH image software (V.1.44). A threshold value was chosen to eliminate background noise before images were analyzed. A mean gray value per unit area was determined for each cell. Lower gray values indicated brighter fluorescence with $1=$ white and $255=$ black on a 256 grayscale. Data were collected as the area of staining multiplied by the average intensity of staining.

Colocalization analysis. The "colocalization" function of the Zeiss LSM410 system was used to measure the areas of SV2 and rab6 costaining in TGNs of photoreceptors (this method will be described in detail in a separate paper; E. Townes-Anderson and N. Zhang, unpublished observations). Briefly, cone and rod cells were identified morphologically with transmitted light, and parameters for sensitivity and contrast were set separately for cone and rod cells. Optical sections $(1 \mu \mathrm{m})$ were taken at a level containing the Golgi apparatus as determined by prominent rab6 staining. For every pixel in the original image, the system plots a corresponding point relating to the intensities of the red and green channels. On the resulting scattergram, the $x$-axis represents the intensity of pixels in the red channel, and the $y$-axis represents the intensity of pixels in the green channel. If a pixel has equal intensities in both channels, then the point will fall on a $45^{\circ}$ line in the center of the graph. The farther away the points are from the $45^{\circ}$ line, the higher the intensity is for one channel compared with the other. In our colocalization analysis, an arbitrary but consistently applied threshold was chosen by marking a constant rectangular area on the scattergram so that background signals were excluded and pixels with high intensities in both channels were captured appropriately. Data were collected as the total area of double-labeled pixels.

Data analysis. Cell cultures contained a mixed population of retinal neurons. Photoreceptors can always be identified by the presence of an ellipsoid, an accumulation of mitochondria in the inner segment. Rod and cone cells were identified by the presence and absence, respectively, of $\mathrm{M}(\mathrm{red})$ rod opsin immunostaining using monoclonal antibody 4D2. $\mathrm{S}$ (green) rod cells were thus excluded from the rod cell category and may have been included in the cone cell category. They are, however, only $1.3 \%$ of the total photoreceptor population in tiger salamander (Sherry et al., 1998). Both single and double cones were included. In experiments double labeled for rab6 and SV2, cells were identified by phase-contrast microscopy before analysis by confocal microscopy. Identification by light microscopy was based on cell soma shape, thickness of processes, and shape of varicosities. Cone cells tend to have an elliptical soma, broad processes, and triangular varicosities compared with rod cells. Only cells that were felt to be positively either rod or cone were used for analysis.

The data were collected only from photoreceptors without outer segments. All cone cells retain their axon terminals after retinal dissociation; rod cells can either retain or lose their axon and terminal. Rod cells with axons display structural rearrangement followed by development of neurites and varicosities, whereas rod cells without axons form neurites and varicosities de novo. These two types of rod cells were previously termed denervated and axotomized, and they differ in the rate of development but not in the type of processes and presynaptic structures that are formed (Nachman-Clewner and Townes-Anderson, 1996).

The data are expressed as mean \pm SEM. Statistical comparisons between two groups were made with the Student's $t$ test, if the normality and equal variance tests were passed, or with the Mann-Whitney rank sum test, if the normality and equal variance tests failed. Comparisons among multiple groups were made with one-way ANOVA. The post hoc analysis used with the one-way ANOVA was Dunnett's method. Statistical analysis was performed using SigmaStat software (V2.0). Data graphs were created using SigmaPlot software (V5.0).

\section{RESULTS}

Antagonists for the selective blockage of L-type calcium channels are divided into three classes: dihydropyridines, benzothiazepines, and phenylalkylamines. Reagents from these classes bind to the pore-forming $\alpha_{1}$ subunit of the channel (Hockerman et al., 1997a,b; Peterson et al., 1997; Catterall, 2000). In the present series of experiments, the dihydropyridine antagonist nicardipine and the phenylalkylamine antagonist verapamil were used to selectively block the L-type channels of photoreceptors. For the blockage of cGMP-gated channels, the transition metal cobalt bromide and the benzothiazepine antagonist L-cis-diltiazem were used. However, the effects of $\mathrm{CoBr}$ and Lcd are not specific: $\mathrm{CoBr}$ blocks all types of calcium channels (Hille, 1992), whereas Lcd, an isomer of the L-type channel antagonist D-cis-diltiazem and a potent blocker of photoreceptor cGMP-gated channels (Stern et al., 1986; Quandt et al., 1991), can still bind to L-type channels with low affinity (Ikeda et al., 1991). Reagents that more specifically block cGMP-gated channels are not available currently. Therefore, $8 \mathrm{Br}-\mathrm{cGMP}$, which can induce $\mathrm{Ca}^{2+}$ current specifically through photoreceptor cGMP-gated channels (Rebrik and Korenbrot, 1998; Xiong et al., 1998), was used to activate cGMPgated channels.
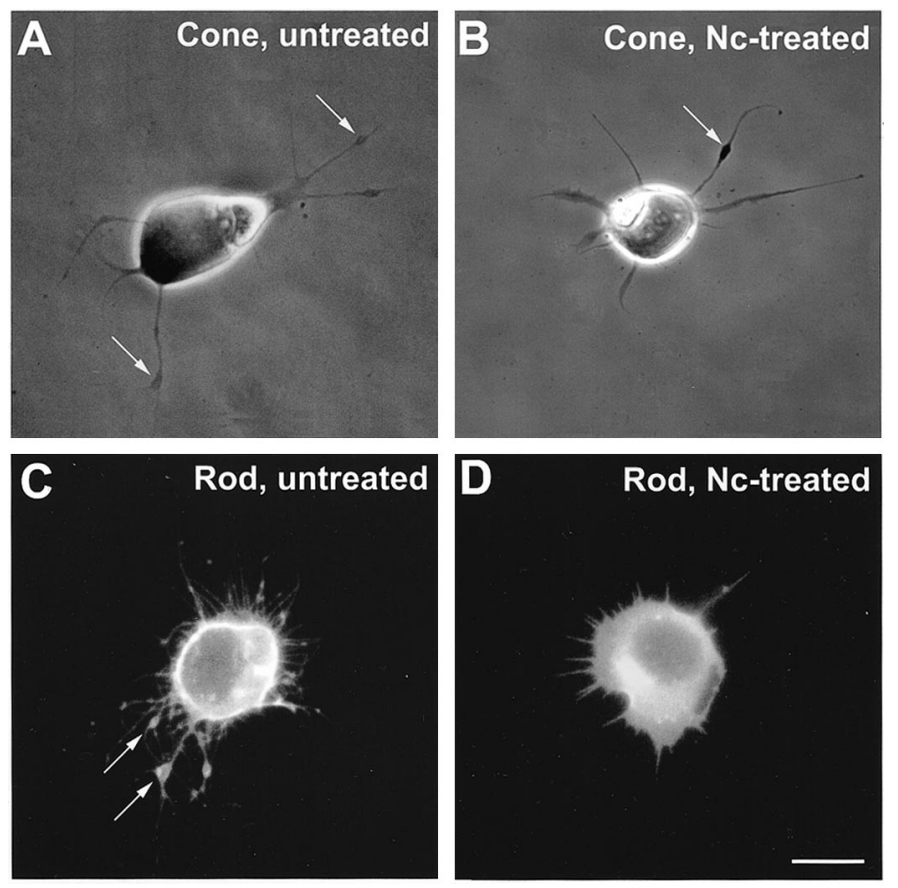

Figure 2. Morphological changes of photoreceptors treated with nicardipine. $A$, Phase-contrast microscopy of an untreated cone cell. Neuritic processes with branching structures were present. Varicosities (arrows) had formed along the processes. B, Nc-treated cone cell. Processes showed fewer branches, but varicosities (arrow) had still formed along the processes. $C$, Fluorescence microscopy of an untreated rod cell labeled with rod opsin antibody. The rod cell showed prominent process outgrowth with obvious branching. Multiple varicosities (arrows) had formed along the thicker processes, the neurites. $D$, Nc-treated rod cell labeled with rod opsin antibody. The rod cell showed fewer processes and no varicosities. Cells were from 3-d-old cultures; Nc treatment started after $1 \mathrm{~d}$ in culture. Scale bar, $10 \mu \mathrm{m}$. 


\begin{tabular}{|c|c|c|c|c|c|c|}
\hline \multirow[b]{2}{*}{ Categories } & \multicolumn{3}{|c|}{ Two days in culture } & \multicolumn{3}{|c|}{ Three days in culture } \\
\hline & Nc treated & Control & $t$ test ( $p$ value) & Nc treated & Control & $t$ test ( $p$ value) \\
\hline \multicolumn{7}{|l|}{ Cones } \\
\hline Cells analyzed & 110 & 110 & & 110 & 110 & \\
\hline Total processes & 800 & 835 & & 797 & 914 & 0.007 \\
\hline $1^{\circ}$ Processes & 552 & 526 & & 558 & 577 & \\
\hline $2^{\circ}$ Processes & 229 & 269 & & 228 & 274 & 0.049 \\
\hline $3^{\circ}$ Processes & 19 & 40 & 0.021 & 11 & 63 & 0.001 \\
\hline Lamellipodia & 59 & 57 & & 39 & 46 & \\
\hline Thick processes & 228 & 230 & & 301 & 272 & \\
\hline Thin processes & 265 & 239 & & 218 & 259 & \\
\hline Varicosities & 25 & 30 & & 45 & 63 & \\
\hline \multicolumn{7}{|l|}{ Rods } \\
\hline Cells analyzed & 110 & 110 & & 110 & 110 & \\
\hline Total processes & 1716 & 1754 & & 2399 & 3065 & 0.001 \\
\hline $1^{\circ}$ Processes & 1248 & 1199 & & 1647 & 2006 & 0.017 \\
\hline $2^{\circ}$ Processes & 454 & 514 & & 714 & 892 & 0.010 \\
\hline $3^{\circ}$ Processes & 14 & 41 & 0.008 & 38 & 167 & $<0.001$ \\
\hline Lamellipodia & 63 & 68 & & 57 & 50 & \\
\hline Thick processes & 54 & 73 & & 48 & 89 & 0.017 \\
\hline Thin processes & 1131 & 1059 & & 1542 & 1867 & 0.041 \\
\hline Varicosities & 22 & 45 & 0.047 & 65 & 207 & $<0.001$ \\
\hline
\end{tabular}

Rod cells labeled with 4D2 antibody were viewed with fluorescence microscopy, whereas cone cells were viewed with phase-contrast microscopy.

\section{Blockage of L-type calcium channels with nicardipine or verapamil: effects on neuritic processes and varicosities}

Previous studies demonstrated that an immediate blockage of L-type channels with $\mathrm{Nc}$ inhibited axonal retraction in rod cells and caused a reduction of process growth in photoreceptors, including both the cone and the rod cells (Nachman-Clewner and Townes-Anderson, 1999). Effects of L-type channel antagonists applied at later stages of neuritic and varicosity development were not tested. Therefore, the questions first addressed were (1)
Figure 3. Effect of nicardipine $(N c)$ treatment and removal on the growth of processes and varicosities by photoreceptors as determined by quantitative analysis. $A$, Growth of neuritic processes. Nc treatment caused a significant decrease in the total number of processes per cell as compared with controls in both cone and rod cells from 3-d-old cultures. $B$, Growth of varicosities. Nc-treated rod cells from both 2- and 3-d-old cultures showed a significant decrease in the number of varicosities as compared with controls. The decrease in cone cells did not reach statistical significance. $C$, Growth of neuritic processes after removal of Nc. Nc was removed from the medium, and photoreceptors were cultured for an additional $3 \mathrm{~d}$; there was a prominent growth of processes in rod cells, but no change in the total number of processes from cone cells. $D$, Growth of varicosities after removal of Nc. After $\mathrm{Nc}$ was removed from the medium and photoreceptors were cultured for another $3 \mathrm{~d}$, there was also a prominent increase in the number of varicosities in rod cells. In cone cells, no significant growth of processes or varicosities was seen after removal of Nc. A total of 880 cells in 14 cultures from three animals were analyzed in $A$ and $B$, and a total of 250 cells in 10 cultures from one animal were analyzed in $C$ and $D$.
A

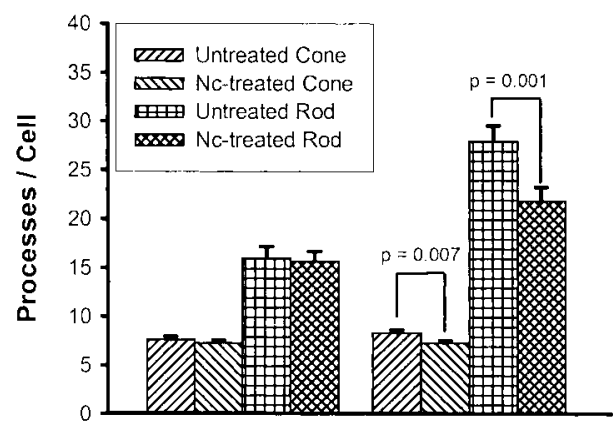

2 Day Old Culture 3 Day Old Culture

C

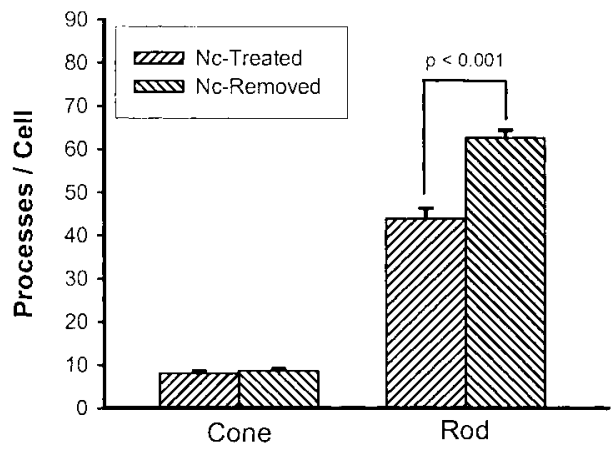

B

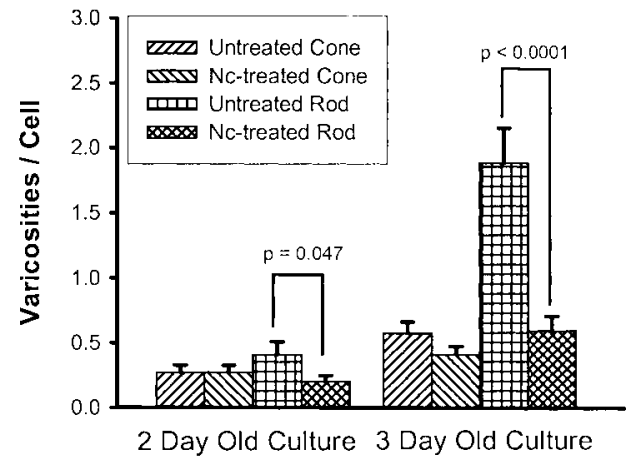

D

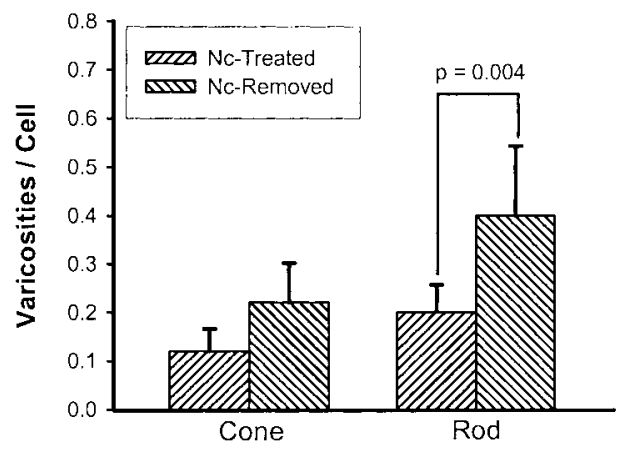


whether the development of neuritic processes and the formation of presynaptic varicosities by cone and rod cells require $\mathrm{Ca}^{2+}$ influx through L-type calcium channels and (2) whether continuous $\mathrm{Ca}^{2+}$ influx or a brief period of $\mathrm{Ca}^{2+}$ influx through L-type channels is required. Photoreceptors were cultured in antagonistfree medium to allow $\mathrm{Ca}^{2+}$ influx for $1 \mathrm{hr}$ or $1 \mathrm{~d}$. Then, $10 \mu \mathrm{M} \mathrm{Nc}$ in $0.1 \%$ DMSO was added to the medium, and cells were cultured for an additional $2 \mathrm{~d}$ (Fig. 1). Two types of controls were included: (1) cells were treated with $0.1 \%$ DMSO alone for the entire period, and (2) cells with Nc treatment were returned to normal medium after $3 \mathrm{~d}$ in culture (Fig. 1).

During the first 2-3 d in culture in Nc-free medium, growth of neuritic processes with branching structures as well as formation of presynaptic varicosities were observed in both cone and rod cells (Fig. $2 A, C$ ). For cone cells, 7.64 processes per cell and 0.27 varicosities per cell were observed in 2-d-old cultures, whereas 8.32 processes per cell and 0.57 varicosities per cell were observed in 3-d-old cultures (Table 1, Fig. $3 A, B$ ); varicosity development was statistically significant during this period $(p<0.01)$. For rod cells, 15.95 processes per cell and 0.41 varicosities per cell were observed in 2-d-old cultures, whereas 27.90 processes per cell and 1.88 varicosities per cell were observed in 3 -d-old cultures on average (Table 1, Fig. $3 A, B)$; both neurite outgrowth $(p<0.001)$ and varicosity development $(p<0.001)$ were significantly increased from 2 to $3 \mathrm{~d}$ in cultured rod cells. In a few rod cells grown in antagonist-free medium, as many as 11 varicosities were observed in a single cell. Thus, in this culture system, rod cells grew more processes and formed more varicosities than cone cells, and the period of the first $2-3 \mathrm{~d}$ in culture was a critical period for the development of axonal structures for both cone and rod cells. These data were consistent with previously reported results (Mandell et al., 1993; Sherry et al., 1998).

The blockage of L-type calcium channels caused changes in

\begin{tabular}{|c|c|c|c|}
\hline Categories & $\begin{array}{l}\text { Nc treated } \\
(3 \mathrm{~d} \text { culture })\end{array}$ & $\begin{array}{l}\text { Nc removed } \\
(6 \mathrm{~d} \text { culture })\end{array}$ & $t$ test ( $p$ value) \\
\hline \multicolumn{4}{|l|}{ Cones } \\
\hline Cells analyzed & 50 & 50 & \\
\hline Total processes & 402 & 433 & \\
\hline $1^{\circ}$ Processes & 247 & 224 & \\
\hline $2^{\circ}$ Processes & 144 & 184 & \\
\hline $3^{\circ}$ Processes & 11 & 25 & 0.038 \\
\hline Lamellipodia & 19 & 40 & 0.012 \\
\hline Thick processes & 116 & 117 & \\
\hline Thin processes & 112 & 67 & 0.011 \\
\hline Varicosities & 6 & 11 & \\
\hline \multicolumn{4}{|l|}{ Rods } \\
\hline Cells analyzed & 75 & 75 & \\
\hline Total processes & 3433 & 4787 & $<0.001$ \\
\hline $1^{\circ}$ processes & 2433 & 3166 & $<0.001$ \\
\hline $2^{\circ}$ processes & 951 & 1410 & $<0.001$ \\
\hline $3^{\circ}$ processes & 49 & 263 & $<0.001$ \\
\hline Lamellipodia & 6 & 11 & 0.012 \\
\hline Thick processes & 170 & 148 & \\
\hline Thin processes & 2257 & 2955 & 0.011 \\
\hline Varicosities & 12 & 40 & 0.004 \\
\hline
\end{tabular}

Rod cells labeled with 4D2 antibody were viewed with fluorescence microscopy, whereas cone cells were viewed with phase-contrast microscopy. photoreceptor growth patterns that were more prominent in rod than cone cells (Fig. 2B,D). Additionally, compared with controls, Nc-treated photoreceptors from 3-d-old cultures showed more significant changes in growth than 2-d-old cultures (Table 1, Fig. $3 A, B)$. In 3-d-old cultures, for instance, Nc reduced the number of neuritic processes by $21.8 \%$ in rod cells and by $14.1 \%$ in cone cells. Among all subtypes of processes, $3^{\circ}$ processes, small-branching structures, were the most affected (Table 1). Nc-treated rod cells also showed a significant decrease in the number of varicosities, with a $51.1 \%$ reduction in 2-d-old cultures and a $68.6 \%$ reduction in 3 -d-old cultures (Table 1 , Fig. $3 B$ ). In Nc-treated cone cells, the decrease in varicosity number, although present, was not statistically significant (Table 1, Fig. 3B). These data show that although blockage of L-type calcium channels inhibited process outgrowth in both cone and rod cells, varicosity formation was significantly inhibited only in rod cells.

To exclude the possibility that the inhibition of $\mathrm{Nc}$ was caused by toxicity, neuritic structures were analyzed after Nc was removed from the medium and cells were allowed to grow for an additional $3 \mathrm{~d}$. After $\mathrm{Nc}$ removal, both cone and rod cells resumed growth of processes, and varicosity development resumed in rod cells (Table 2, Fig. 3C,D). Furthermore, Nc treatment caused no reduction of photoreceptor cell density (data not shown). Thus, Nc-treated cells were viable, and no cell death occurred.

The phenylalkylamine antagonist verapamil (5 $\mu \mathrm{M})$ was also used to block L-type calcium channels. Delayed (after 1 d) blockage of L-type calcium channels by Vrp significantly inhibited varicosity formation by $31.5 \%$ in rod but not in cone cells. Thus, another class of L-type channel antagonist gave results consistent with Nc (Fig. 4).

\section{Blockage of L-type calcium channels with nicardipine: effects on synaptic vesicle proteins}

Presynaptic varicosities are formed by photoreceptors as synaptic vesicles accumulate near the terminals of neurites (Mandell et al., 1993). In the previous section, inhibition of varicosity formation by Nc was observed. This inhibition could be caused by (1) the inhibition of vesicle protein synthesis or (2) the inhibition of anterograde vesicle transport in neurites, or both. Because reduced vesicle protein synthesis could also explain reduced transport, we chose to investigate the synthesis of vesicle proteins, specifically SV2 and synaptophysin, in Nc-treated cone and rod cells.

Proteins synthesized in the endoplasmic reticulum (ER) are transported peripherally after maturation and packaging in the Golgi complex. The level of protein in the Golgi complex gives some indication of the level of protein synthesis in the ER (Hannah et al., 1999). Indeed, cycloheximide, which blocks protein synthesis in general, reduced opsin in the Golgi complex of rod cells as seen with double immunolabeling (Townes-Anderson, unpublished data). We used this principle in conjunction with image analysis to analyze relative levels of synthesis of synaptic vesicle protein in different cell types, the cone and rod cells, in the same culture. In the first series of experiments, the presence of synaptic vesicle protein SV2 in the trans-Golgi network was analyzed by colabeling for SV2 and a TGN marker protein, rab6 (Fig. 5). Three-day-old cultures that had been treated with $\mathrm{Nc}$ for $2 \mathrm{~d}$ were examined. The confocal microscopic images of untreated cone and rod cells showed strong SV2 immunostaining in the rab6-positive Golgi area (Fig. 6A,C). After Nc treatment, the TGN in cone cells continued to have strong SV2 labeling, whereas that in rod cells had reduced SV2 staining (Fig. 6B,D). Colocalization analysis of rab6 and SV2 

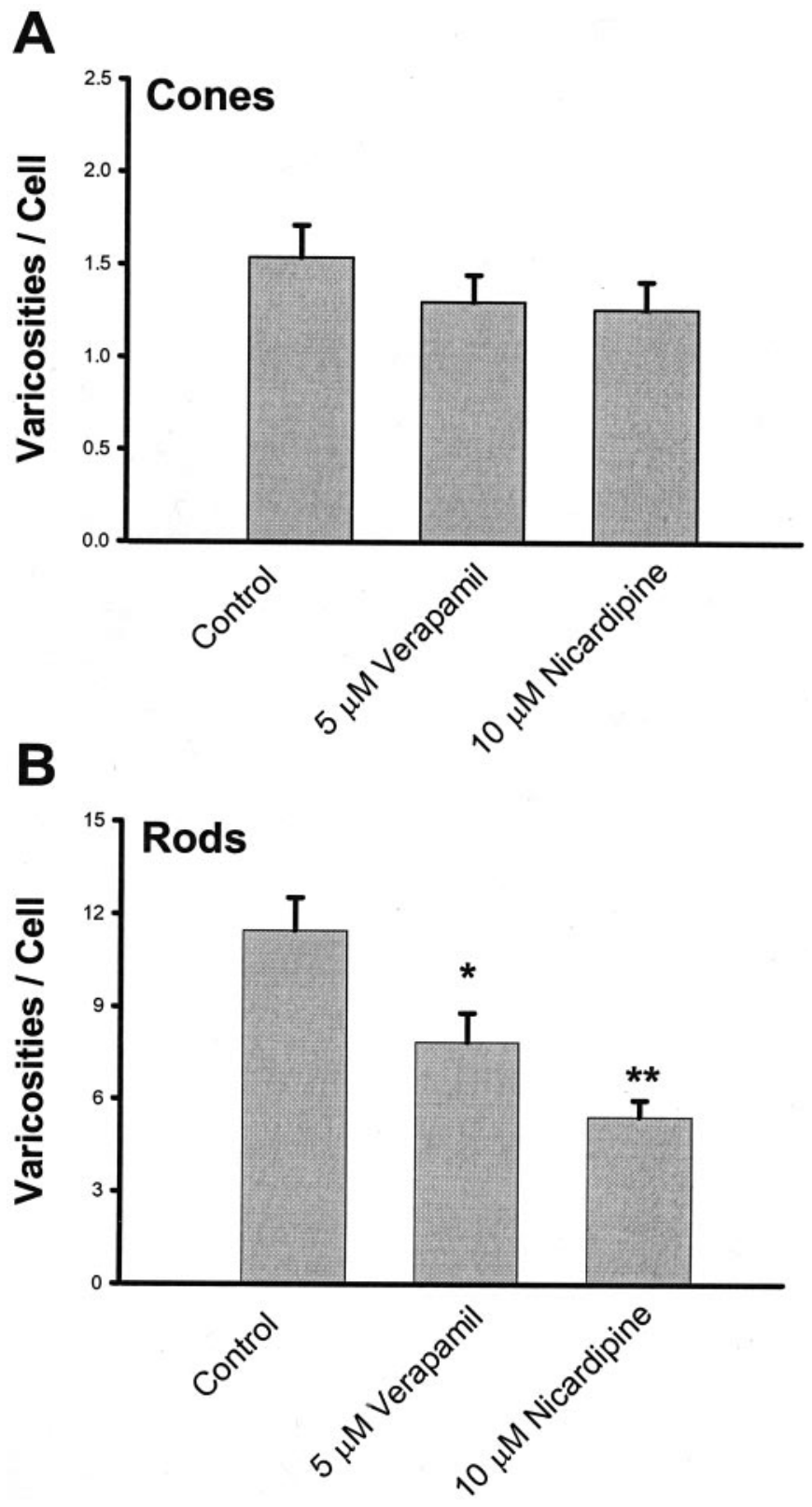

Figure 4. Effect of verapamil treatment on the growth of varicosities by photoreceptors in 3-d-old cultures. $A$, Growth of varicosities by cone cells. Neither $5 \mu \mathrm{M}$ Vrp nor $10 \mu \mathrm{M}$ Nc caused significant inhibition of varicosity formation in cone cells. $B$, Growth of varicosities by rod cells. Both $5 \mu \mathrm{M}$ Vrp and $10 \mu \mathrm{M}$ Nc caused significant inhibition of varicosity formation in rod cells. A total of 300 cells in eight cultures from one animal were analyzed. ${ }^{*} p<0.05 ;{ }^{*} p<0.01$.

immunostaining further demonstrated that the Nc treatment did not cause a decrease in the area of colocalization in cone cells but did cause a significant $59.1 \%$ decrease in the area of colocalization in rod cells (Fig. 7A). After Nc was removed from the medium and cells were cultured for 3 more days, the average area of colocalized rab6 and SV2 staining in Nc-treated cone cells was unchanged, but the average colocalization area of rab6 and SV2 in Nc-treated rod cells showed a $117.5 \%$ increase in size (Fig. $7 B$ ). These data demonstrated that delayed blockage of L-type calcium channels did not influence the synthesis of vesicle protein SV2 in cone cells but sensitively and reversibly inhibited the synthesis of vesicle protein SV2 in rod cells.

\section{SV2 \\ rab6 \\ SV2+rab6}

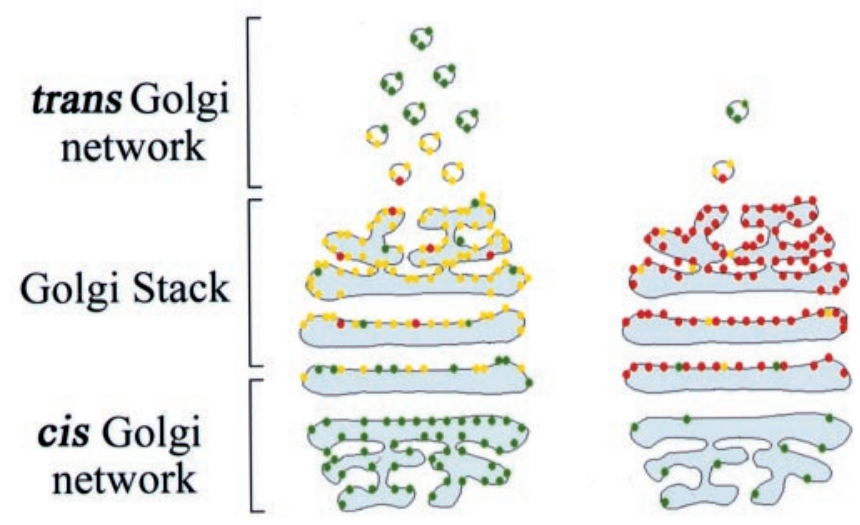

Figure 5. Diagram of expected Golgi labeling in the presence and absence of protein synthesis. Left panel, Double staining of the Golgi apparatus by SV2 (green) and rab6 (red). When SV2, an integral membrane protein of all vesicles, is being synthesized, it appears in the Golgi as well as other locations in the cell. Rab6 is present only in the transGolgi network and post-Golgi vesicles. Double staining (yellow) indicates the presence of SV2 and rab6 in the TGN. Yellow stain will only appear when SV2 is being actively synthesized and is passing through the TGN. Right panel, When no SV2 is synthesized, there is little double staining. SV2 may be present in the cell soma but is in low levels in the Golgi apparatus. Rab6 staining occurs in the trans-Golgi, and a red body appears in the cell soma. Thus, the area of double staining gives an indication of the amount of SV2 synthesis.

To test for the possibility that the Nc-induced inhibition of SV2 in the Golgi was a nonspecific effect and that all protein synthesis was reduced when calcium channels were blocked, the colocalization analysis was applied to rod opsin, a protein that appears to be constitutively expressed in cultured rod cells (Nachman-Clewner and Townes-Anderson, 1996). Nc-treated rod cells showed no significant decrease of the area of colocalization for rab6 and rod opsin as compared with untreated rod cells (Fig. $7 C$ ). The data show not only that opsin expression is not influenced by L-type channel blockage, but also that rab6 expression is unchanged. Thus, the reduction of SV2 synthesis in rod cells by L-type channel blockage represents a specific effect and not a general depression of protein synthesis.

To confirm the data obtained with SV2, the effects of L-type channel blockage on the level of another vesicle protein, synaptophysin, in photoreceptors was investigated. Cultured photoreceptors were divided into four groups: (1) untreated, cells were cultured in Nc-free medium for $3 \mathrm{~d}$; (2) Nc-treated, cells were cultured in Nc-containing medium for $2 \mathrm{~d}$ after $1 \mathrm{~d}$ preincubation in Nc-free medium; (3) Nc-removed, Nc-treated cells were subsequently cultured in Nc-free medium for 3 more days; and (4) Nc-remained, Nc-treated cells were cultured in Nc-containing medium for $5 \mathrm{~d}$ after $1 \mathrm{~d}$ in Nc-free medium (see Fig. 9A). Cells were double labeled with synaptophysin and rod opsin antibodies, and confocal microscopic sections were taken at two levels, with one level containing processes and another level containing the Golgi apparatus. Confocal images of cone cells from the above groups showed no significant changes in synaptophysin staining (pictures not shown). However, in confocal microscopic images of rod cells, changes of synaptophysin staining could be observed. In untreated rod cells, strong synaptophysin staining appeared in the 
rab6 + SV2
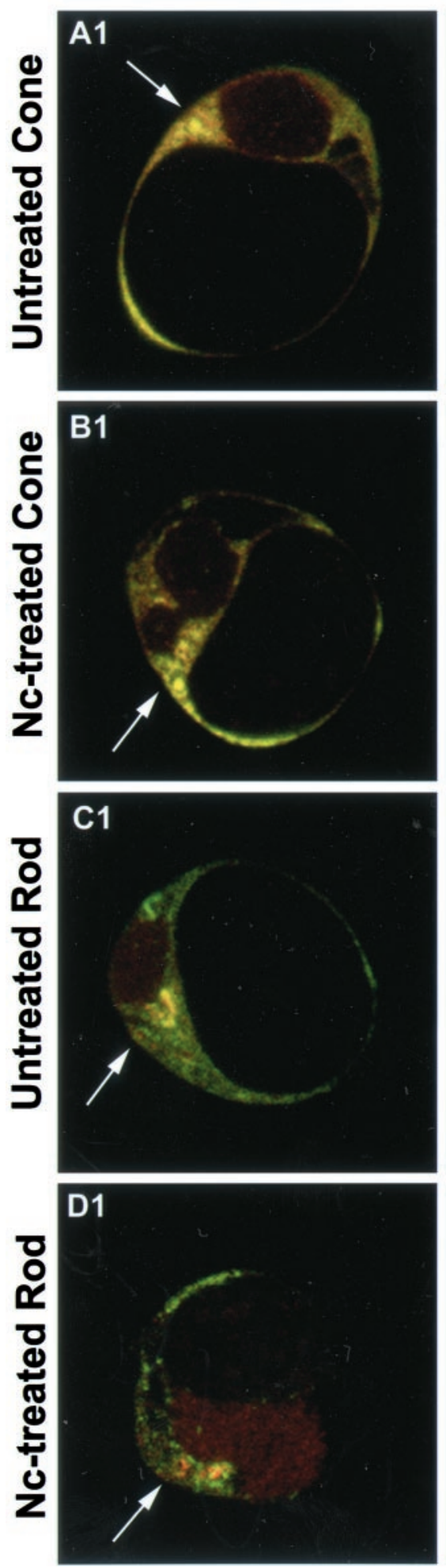

rab6 (red)
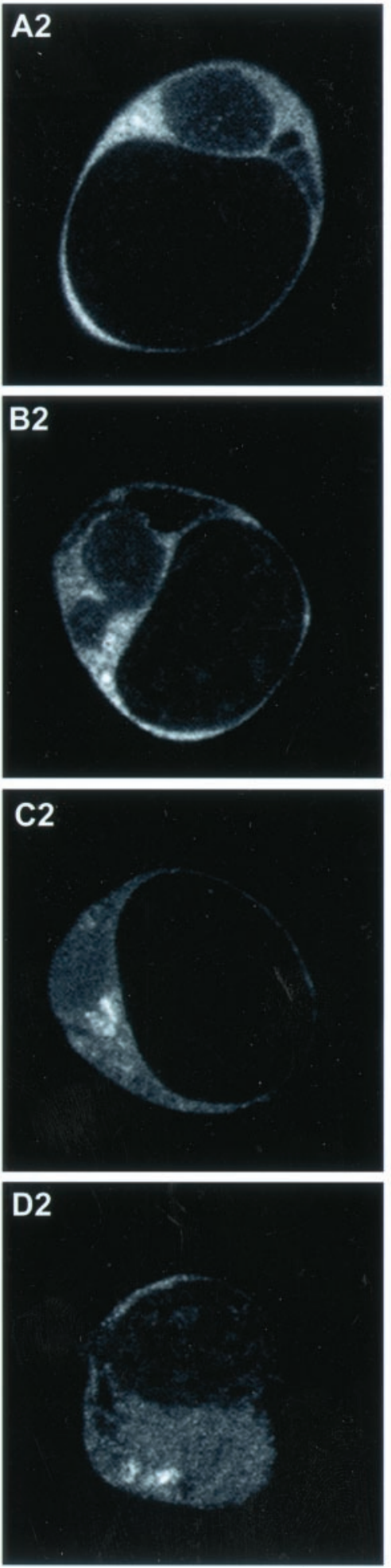

SV2 (green)
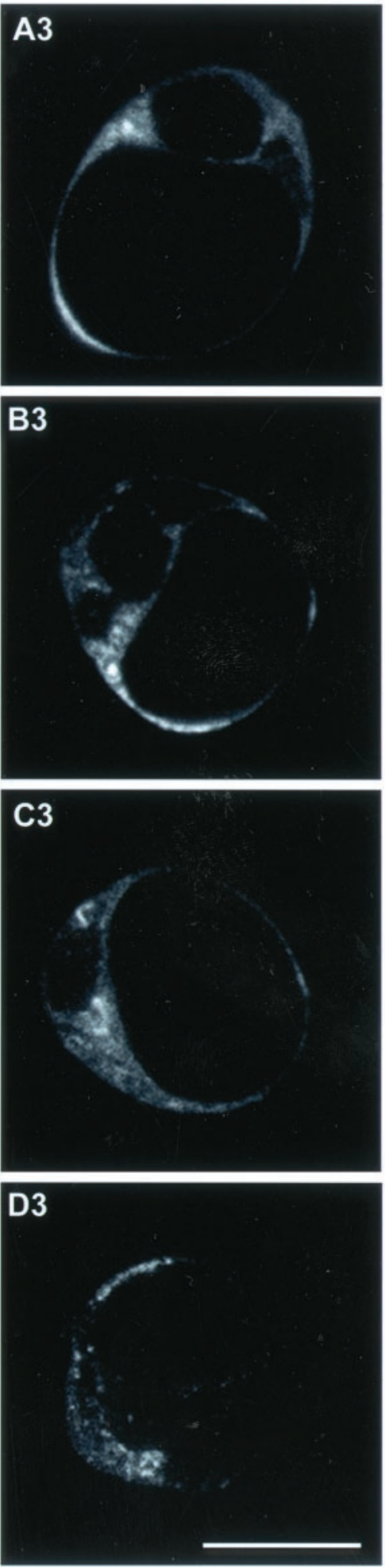

Figure 6. Photoreceptors from 3-d-old cultures double stained with rab6 and SV2 antibodies. Optical sections (1 $\mu \mathrm{m})$ were obtained at a level showing the Golgi apparatus. Images are displayed in red-green-blue $(A 1, B 1, C 1$, and $D 1)$, red $(A 2, B 2, C 2$, and $D 2)$, and green channels $(A 3, B 3, C 3$, and $D 3)$, respectively. $A 1-A 3$, Untreated cone. The Golgi apparatus and post-Golgi vesicles were labeled by rab6 and SV2 antibodies and appeared yellow (arrow), indicating the synthesis of SV2. B1-B3, Nc-treated cone. Nc treatment did not cause an obvious change of rab6 and SV2 staining in the Golgi apparatus, suggesting the continued presence of SV2 in the TGN (arrow). C1-C3, Untreated rod. Both rab6 and SV2 antibodies stained the trans-Golgi apparatus, which appears yellow (arrow). SV2 staining (green) is also present in other locations in the cell soma such as the cis-Golgi. D1-D3, Nc-treated rod. Nc treatment reduced SV2 staining in the Golgi area. The arrow indicates the Golgi apparatus that showed rab6 label (red), but SV2 staining (green) occurred primarily in areas outside the Golgi apparatus. This suggests that SV2 synthesis had been reduced but that SV2, perhaps in old synaptic vesicles, continues to be present in the cell soma. Scale bar, $10 \mu \mathrm{m}$. 


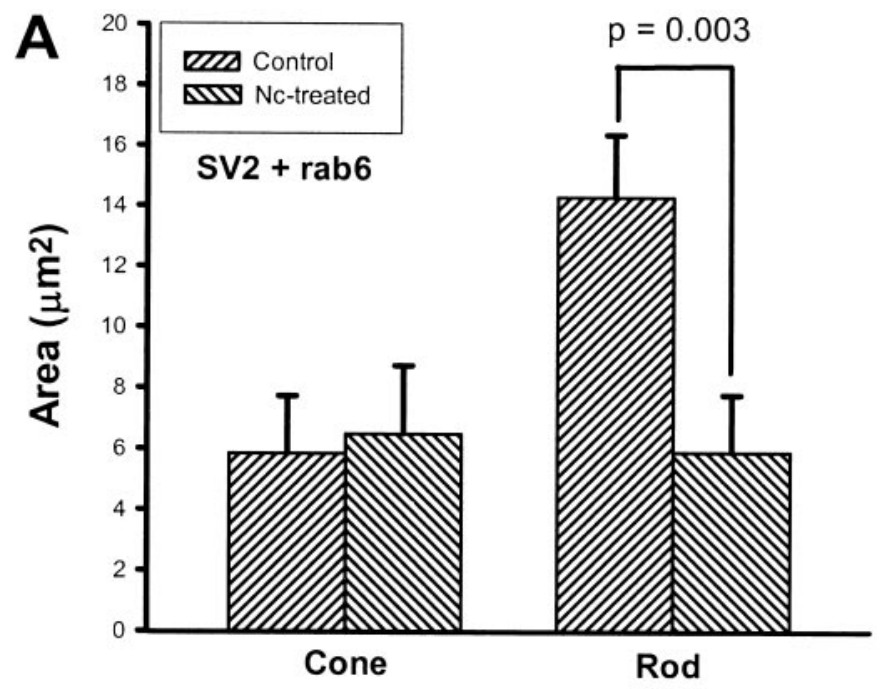

Cell Type
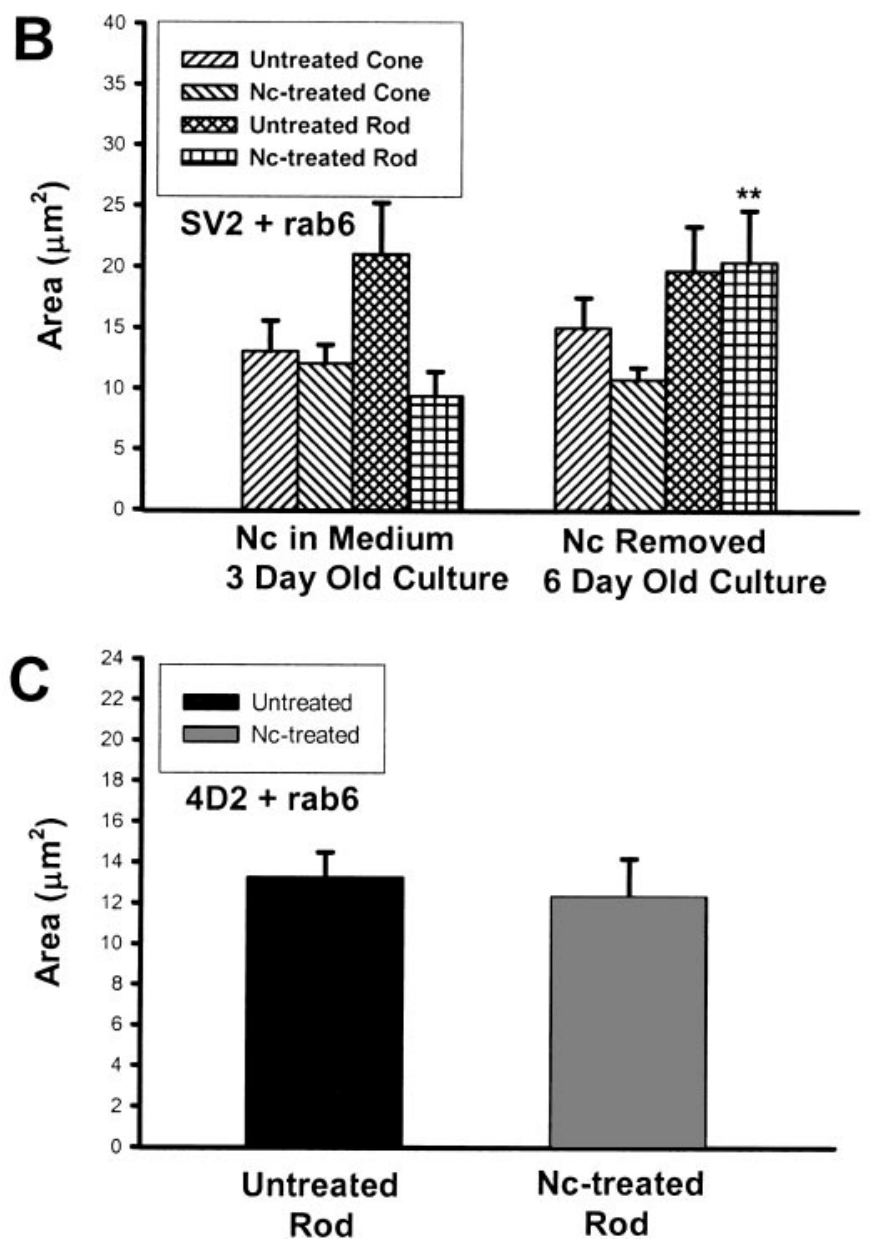

Figure 7. The effects of application and removal of nicardipine $(N c)$ on SV2 and opsin synthesis in photoreceptors as measured with colocalization analysis. Area is derived from the number of pixels labeled by rab6 and either SV2 or opsin antibodies. $A, \mathrm{SV} 2$ and rab6 labeling in cone and rod cells from 3-d-old cultures that had been treated with Nc after $1 \mathrm{~d}$ in culture. In rod cells, the Nc treatment significantly reduced the SV2 labeling in the Golgi, resulting in a smaller average area of colocalized staining. There was no change in cone cells. A total of 120 cells in six cultures from three animals were analyzed. $B, \mathrm{SV} 2$ and rab6 labeling in cone and rod cells from 6-d-old cultures; Nc had been removed at day 3 soma as well as growing varicosities (Fig. $8 A$ ). In the Nc-treated group of rod cells, there was inhibition of process outgrowth and varicosity formation (Fig. 8B), and synaptophysin staining appeared primarily in the soma. After Nc was removed from the medium, regenerating processes and varicosities could be observed in rod cells, and synaptophysin staining appeared in newly formed varicosities (Fig. $8 C$ ). Prolonged Nc treatment caused almost complete disappearance of synaptophysin staining in rod cells (Fig. 8D).

Synaptophysin staining was further analyzed with densitometry of rod and cone cells identified by the presence or absence of 4D2 staining. Densitometric analysis confirmed that Nc treatment significantly decreased synaptophysin immunostaining only in rod and not in cone cells (Fig. 9B,C). The Nc-remained group of cone cells did show a slight decrease in the staining intensity at the process level; however, this decrease was not statistically significant (Fig. 9B). In rod cells, prolonged Nc treatment (Nc-remained group) caused a dramatic decrease in staining intensity $(86.3 \%$ decrease at the process level and $70.2 \%$ decrease at the Golgi level). Removal of Nc (Nc-removed group) from the medium reduced the extent of this decrease $(46.2 \%$ decrease at the process level and $37.1 \%$ at the Golgi level) (Fig. 9C).

Rod opsin staining at the Golgi level was also analyzed with densitometry. Compared with the untreated group, prolonged $\mathrm{Nc}$ treatment in rod cells did not cause a statistically significant decrease in 4D2 staining density (470.4 \pm 51.6 area $\times$ intensity $10^{-3}$ units for the untreated group and $349.8 \pm 41.2$ area $\times$ intensity $10^{-3}$ units for the Nc-remained group; $p=0.076$; a total of $40 \mathrm{rod}$ cells in four cultures from one animal were analyzed).

These data reinforced the selective inhibition of L-type calcium channel blockage on rod cell vesicle protein synthesis.

\section{Blockage of cGMP-gated channels with cobalt bromide or L-cis diltiazem: effects on processes, varicosities, and the vesicle protein SV2}

The results in previous sections established that varicosity formation as well as vesicle protein synthesis in cone cells were resistant to the blockage of L-type calcium channels. This may be explained if (1) varicosity formation and vesicle protein synthesis in cone cells do not require $\mathrm{Ca}^{2+}$ influx or (2), although $\mathrm{Ca}^{2+}$ influx through L-type calcium channels was blocked, other channels exist through which $\mathrm{Ca}^{2+}$ can enter cone cells. To address the above possibilities, all types of calcium channels were blocked by application of cobalt bromide. Delayed blockage of calcium channels with $1 \mathrm{~mm} \mathrm{CoBr}$ inhibited process outgrowth and varicosity formation not only in rod cells but also in cone cells (Fig. 10). In rod cells, there was a $36.0 \%$ reduction of processes and a $79.0 \%$ reduction of opsin-stained varicosities. In cone cells, there was a $57.1 \%$ reduction of processes and a $56.2 \%$ reduction of varicosities (Fig. $10 A, B)$. In addition, there was a $85.3 \%$ decrease in the areas of rab6 and SV2 colocalization in TGNs of CoBr-treated as compared with untreated cone cells (Fig. 10C). Cell density after $\mathrm{CoBr}$ treatment was also analyzed. No decrease in cell density

(Fig. 1). The SV2 staining increased significantly in Nc-treated rod cells after Nc removal, increasing the areas of colocalization $(* * p<0.01)$, but showed no significant change in Nc-treated cone cells. A total of 80 cells in four cultures from one animal were analyzed. $C$, Rod opsin (4D2) and rab6 labeling in rod cells from 3-d-old cultures. No change in the area of double labeling was observed in Nc-treated rod cells compared with untreated cells, suggesting that Nc had no effect on opsin synthesis. A total of 40 cells in four cultures from two animals were analyzed. 

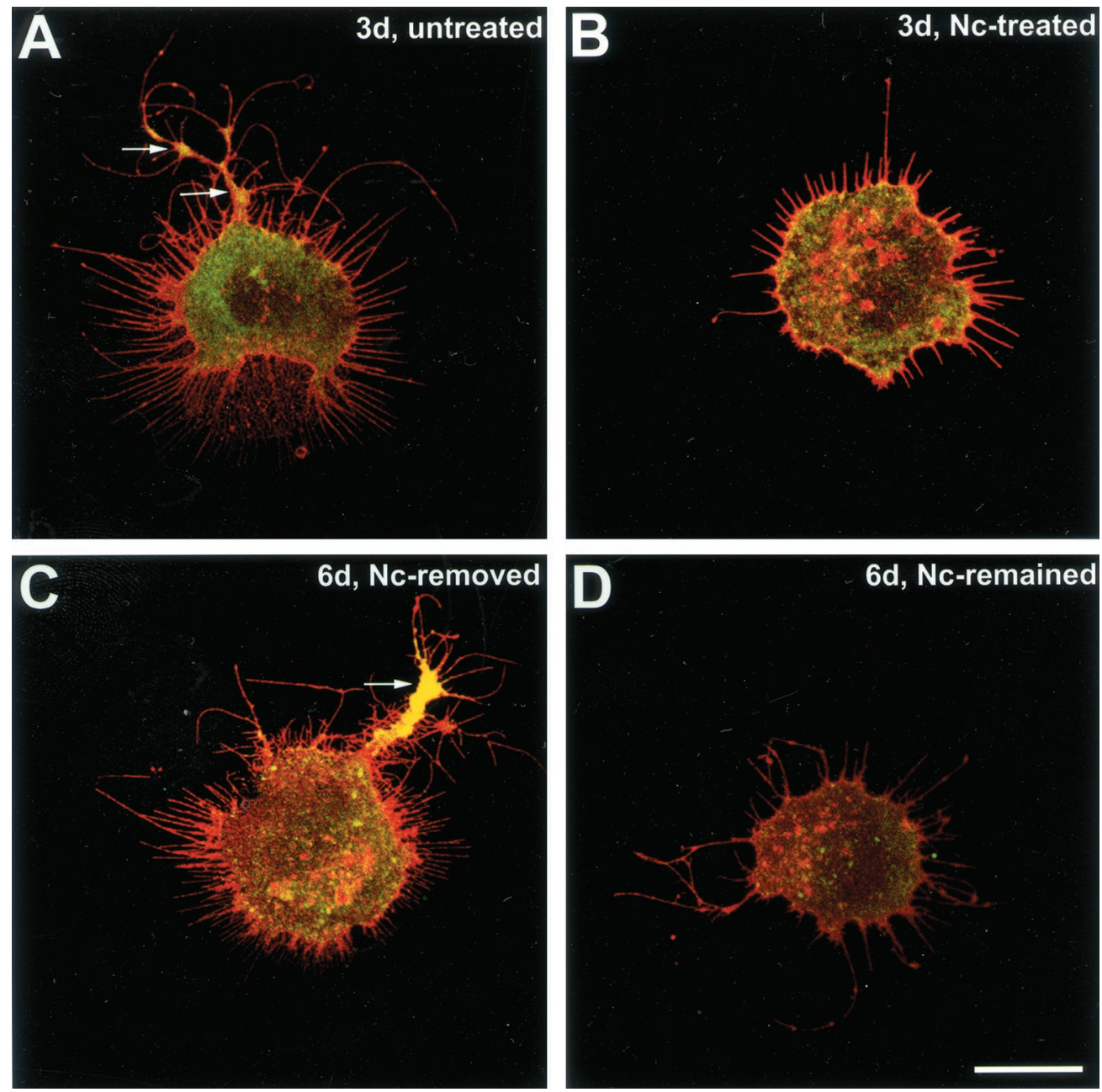

Figure 8. Effect of nicardipine treatment on synaptophysin labeling in photoreceptors. Rod cells were stained with rod opsin (red) and synaptophysin ( green) antibodies. Confocal microscopic sections $(1 \mu \mathrm{m})$ from a level containing processes and varicosities are shown. $A$, An untreated rod cell. The cell had prominent process outgrowth and several varicosities (arrows). Strong synaptophysin staining was present in both the soma and varicosities in the 3-d-old culture. $B$, Nc-treated rod cell. There was clear inhibition of process outgrowth and varicosity formation and weaker synaptophysin staining in the soma in the 3-d-old culture. $C, \mathrm{~A}$ rod cell after Nc removal. The cell had resumed process growth and varicosity formation. Although the synaptophysin staining in the soma was still weak, strong synaptophysin staining was present in varicosities (arrow), suggesting a transport of synaptophysin to peripheral structures from the soma after Nc was removed in the 6-d-old culture. $D$, A rod cell treated with $\mathrm{Nc}$ for $5 \mathrm{~d}$ after $1 \mathrm{~d}$ in Nc-free culture. The prolonged treatment of rod cells with Nc caused a drastic decrease of synaptophysin staining in addition to the inhibition of growth in the 6-d-old culture. Scale bar, $10 \mu \mathrm{m}$. was observed in CoBr-treated as compared with untreated cultures $(101.1 \pm 7.2$ cells $/ 20 \times$ field in CoBr-treated and $92.3 \pm 4.8$ cells $/ 20 \times$ field in untreated cultures; $p=0.417$; a total of 40 fields in four cultures from one animal were analyzed), suggesting that $1 \mathrm{~mm} \mathrm{CoBr}$ was not significantly cytotoxic. These results demonstrated that the development of presynaptic varicosities and the synthesis of SV2 in cone cells required $\mathrm{Ca}^{2+}$ influx. Moreover, it indicated that in cone cells, in addition to L-type calcium channels, there indeed exist channels other than L-type channels that can provide the $\mathrm{Ca}^{2+}$ required for presynaptic development.

As mentioned previously, physiological evidence has shown $\mathrm{Ca}^{2+}$ influx through cGMP-gated channels in the inner segments and synaptic areas of salamander cone cells (Rieke and Schwartz, 1994). L-cis-diltiazem $(100 \mu \mathrm{M})$ was used to block cGMP-gated channels. The delayed administration of Lcd (Fig. 11 $A$ ) caused a $\sim 50 \%$ inhibition of the number of varicosities in cone cells. In rod cells, Lcd gave similar results (Fig. 11B). Combined application of $100 \mu \mathrm{M}$ Lcd and $10 \mu \mathrm{M} \mathrm{Nc}$ did not significantly increase the inhibition. At the same time, $10 \mu \mathrm{M}$ Nc caused significant inhibition of varicosity formation in rod but not cone cells, consistent with previous data (Fig. $11 A, B$ ). In confocal microscopic images, Lcd-treated cone cells showed weaker staining for SV2 and synaptophysin than untreated cone cells (images not shown). Using colocalization analysis, there was a $46.3 \%$ decrease in the areas of rab6 and SV2 double staining in cone cells treated with Lcd as compared with controls (Fig. 11C). Thus, $\mathrm{CA}^{2+}$ influx through
cGMP-gated channels was required by cone cells for formation of presynaptic varicosities and synthesis of vesicle proteins. The effects on rod cells are attributed, at least in part, to the ability of Lcd to block L-type channels.

\section{Effects of activation of cGMP-gated channels with agonist 8Br-cGMP on varicosity formation by cones}

Although $\mathrm{CoBr}$ and Lcd can inhibit varicosity formation, they are not specific antagonists of cGMP-gated channels. One of the characteristics of cGMP-gated channels is that they can be sensitively regulated by intracellular cGMP (Cobbs et al., 1985; Zimmerman, 1995), and cGMP and its analogs, including $8 \mathrm{Br}-\mathrm{cGMP}$, have been used to specifically activate cGMPgated channels (Rebrik and Korenbrot, 1998; Xiong et al., 1998). A further advantage of the application of an analog such as $8 \mathrm{Br}-\mathrm{cGMP}$ is that it activates cGMP-gated channels without stimulating the production of nitric oxide, which has been reported to modulate $\mathrm{Ca}^{2+}$ current in salamander rod cells (Kurenny et al., 1994). We speculated that if $\mathrm{Ca}^{2+}$ influx through cGMP-gated channels could be increased by activation with cGMP analogs, the development of presynaptic varicosities would be stimulated. Three concentrations $(35,350$, and $1400 \mu \mathrm{M})$ of $8 \mathrm{Br}-\mathrm{cGMP}$ were added to the medium, and cells were allowed to grow for $3 \mathrm{~d}$ (Fig. 12A). 8Br-cGMP at $350 \mu \mathrm{M}$ significantly increased varicosity formation in cone cells but significantly decreased varicosity formation in rod cells (Fig. 

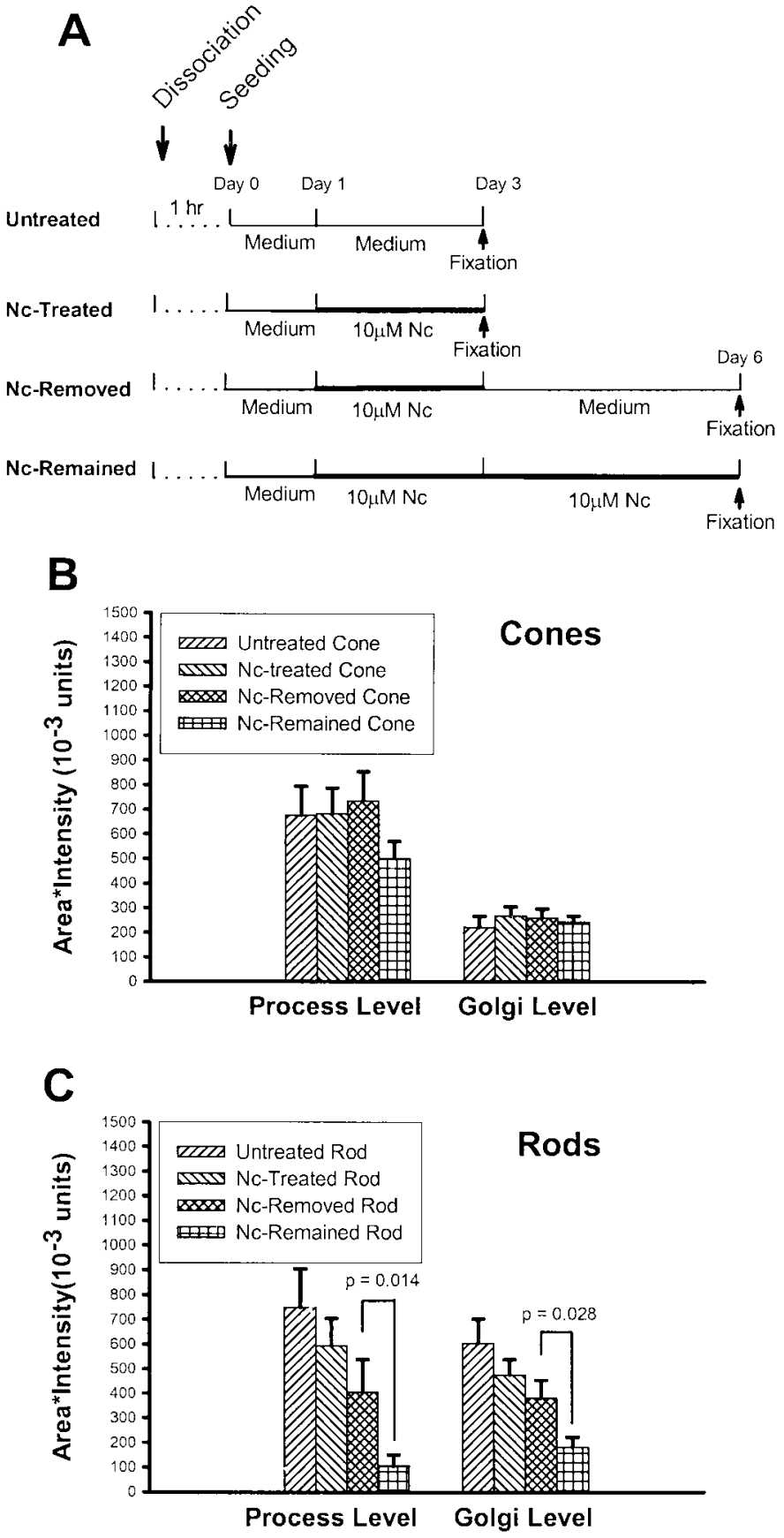

Figure 9. Effect of nicardipine $(N c)$ treatment on synaptophysin staining as measured with densitometric analysis. The analysis was performed on $1 \mu \mathrm{m}$ optical sections taken from a level showing processes and a level showing the Golgi apparatus. $A$, Experimental design for Nc application and Nc removal. Nc $(10 \mu \mathrm{M})$ was added to and removed from the culture medium as indicated. $B$, Densitometry of cone cells. Cone cells did not show a significant decrease of synaptophysin staining intensity in Nctreated, Nc-removed, and Nc-remained groups as compared with the untreated group at both levels. $C$, Densitometry of rod cells. Although rod cells from the Nc-treated group showed only a trend toward decreased synaptophysin staining intensity as compared with the untreated group, prolonged $\mathrm{Nc}$ treatment ( $\mathrm{Nc}$-Remained group) caused a significant decrease in synaptophysin staining intensity at both process and Golgi levels. Removal of Nc from the medium reduced the extent of this decrease (Nc-Removed group). A total of 160 cells in eight cultures from one animal were analyzed.
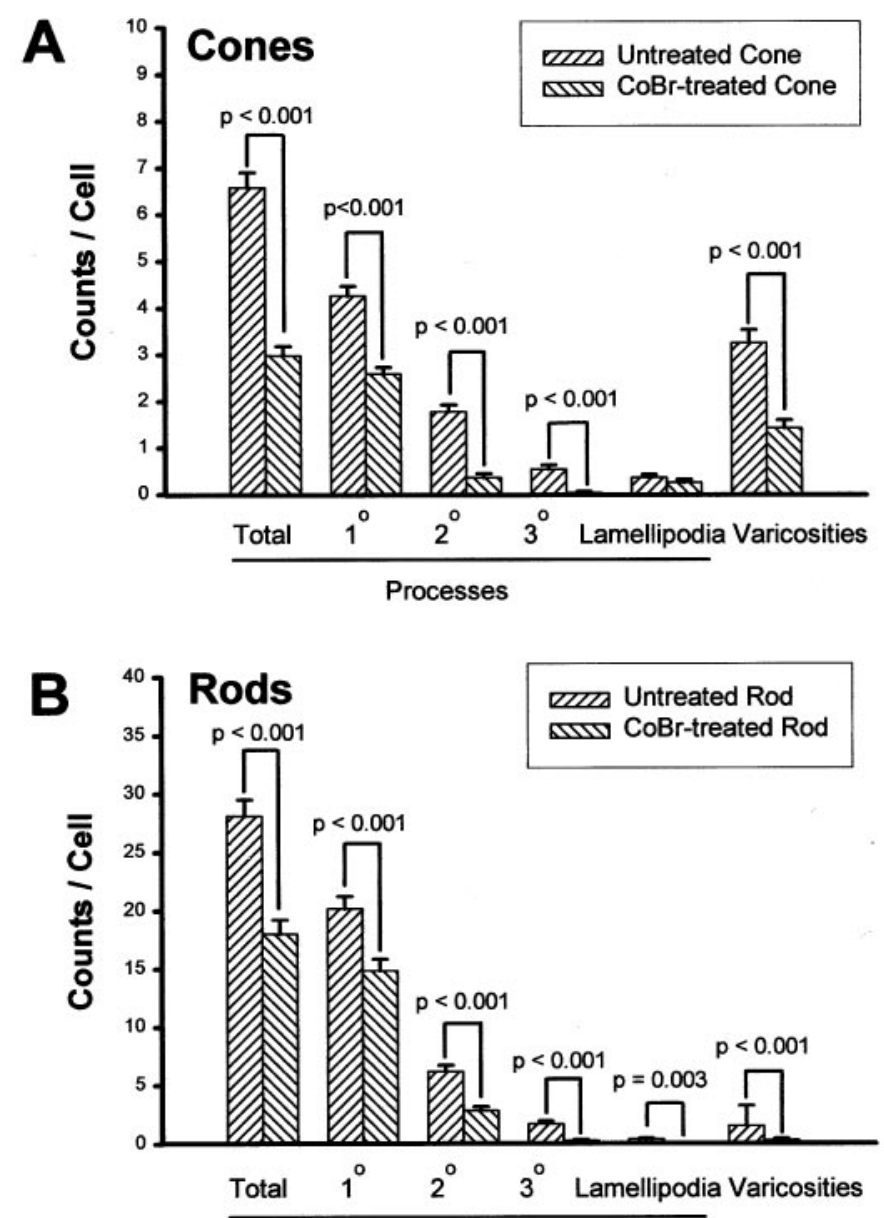

Processes

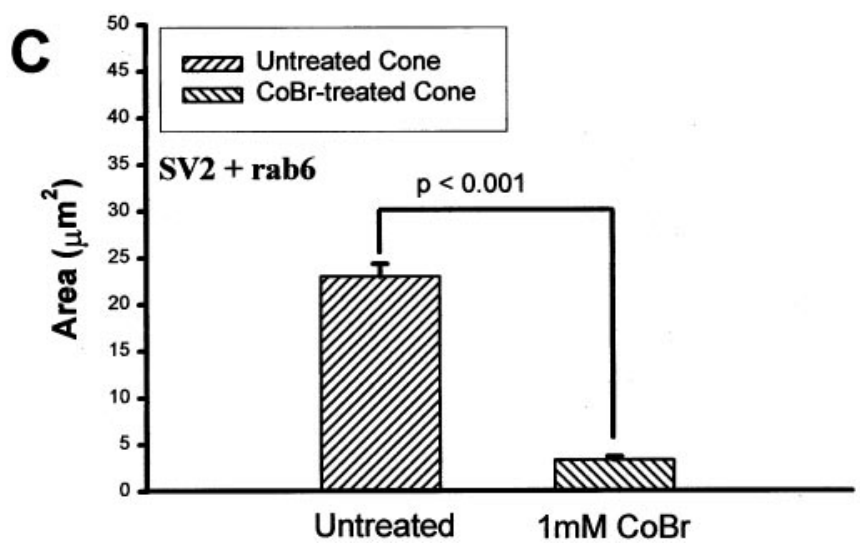

Figure 10. Effects of a $2 \mathrm{~d}$ application of cobalt bromide $(\mathrm{CoBr})$ on process outgrowth, varicosity formation, and SV2 synthesis in 3-d-old cultures. $A$, Process outgrowth and varicosity formation in cone cells. Processes and anti-synaptophysin-labeled varicosities were counted. The $\mathrm{CoBr}$ application significantly reduced the growth of processes and varicosities in cone cells. A total of 200 cone cells in four cultures from one animal were analyzed. $B$, Process outgrowth and varicosity formation in rod cells. Processes and anti-synaptophysin-labeled varicosities were counted. The $\mathrm{CoBr}$ application also significantly reduced the growth of processes and varicosities in rod cells. A total of 200 rod cells in four cultures from one animal were analyzed. Rod and cone cells were identified by the presence and absence, respectively, of rod opsin antibody labeling. $C$, SV2 and rab6 labeling of cone cells. Cone cells treated with $1 \mathrm{~mm} \mathrm{CoBr}$ showed an $85.3 \%$ reduction of the area of colocalized staining. A total of 40 cone cells in four cultures from two animals were analyzed. 

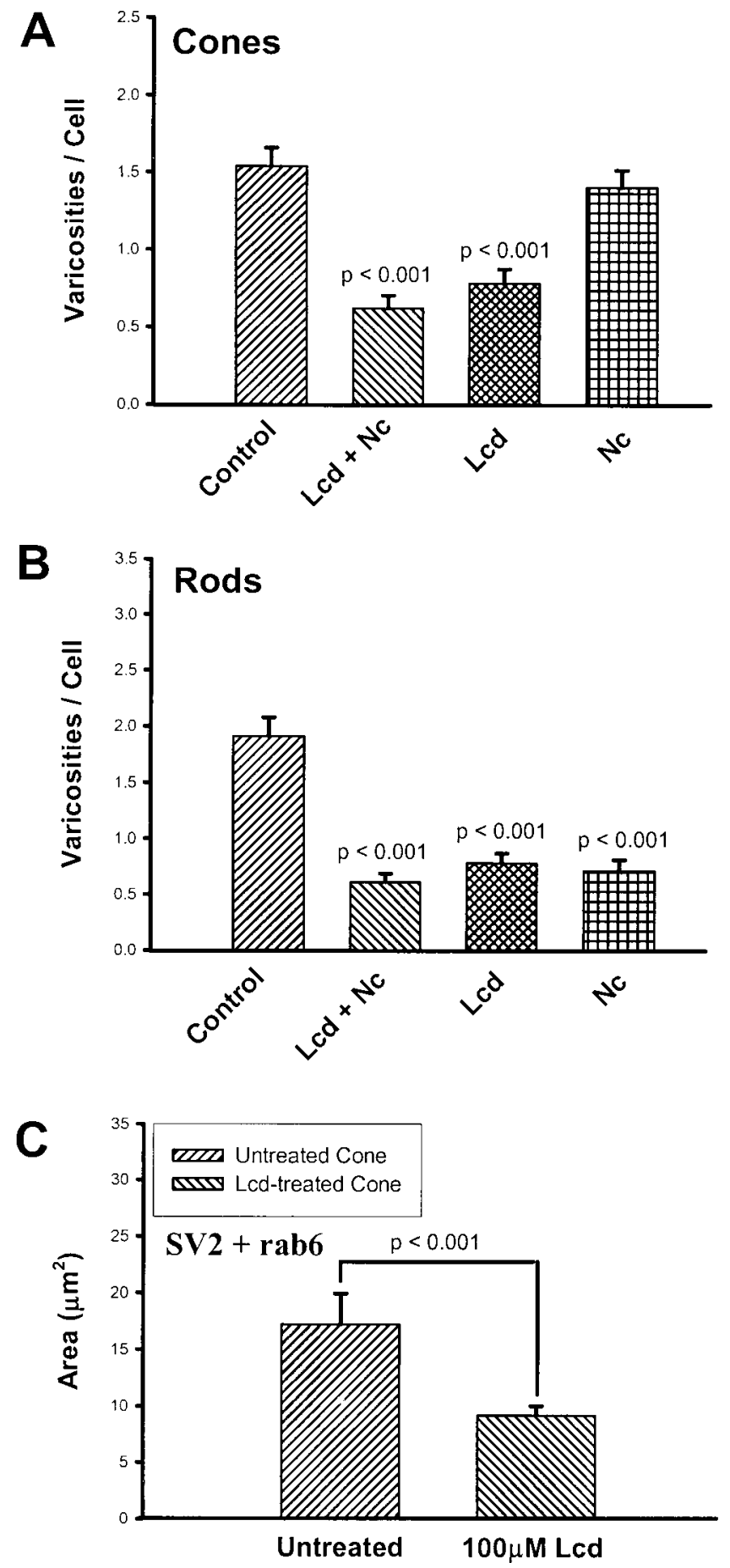

Figure 11. Effects of a $2 \mathrm{~d}$ application of the cGMP-gated channel antagonist L-cis-diltiazem $(L c d)$ on varicosity formation and SV2 synthesis in 3-d-old cultures. $A$, Varicosity formation by cone cells. Varicosities were analyzed with phase-contrast microscopy. Lcd caused a $49.4 \%$ decrease in varicosity production; Lcd plus nicardipine $(L c d+N c)$ also caused a significant decrease, but $\mathrm{Nc}$ alone caused no significant changes in varicosity formation by cone cells. A total of 400 cone cells in 16 cultures from two animals were analyzed. $B$, Varicosity formation by rod cells. Anti-opsinstained varicosities were counted. Both $\mathrm{Nc}$ and Lcd caused significant decreases in varicosity formation by rod cells. A total of 400 rod cells in 16 cultures from two animals were analyzed. $C$, SV2 and rab6 immunocytochemical labeling of cone cells. Cone cells treated with Lcd showed a $46.8 \%$ reduction in the area of colocalized staining, suggesting a decrease in SV2 synthesis. A total of 40 cone cells in four cultures from one animal were analyzed.
A

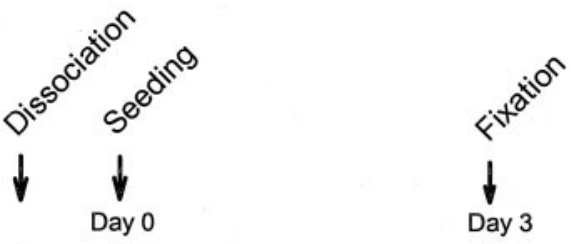

Untreated

$1 \ldots .1$

Medium

8Br-cGMP-treated

$1 \ldots$.

8Br-cGMP

B ${ }^{2.5}$ Cones
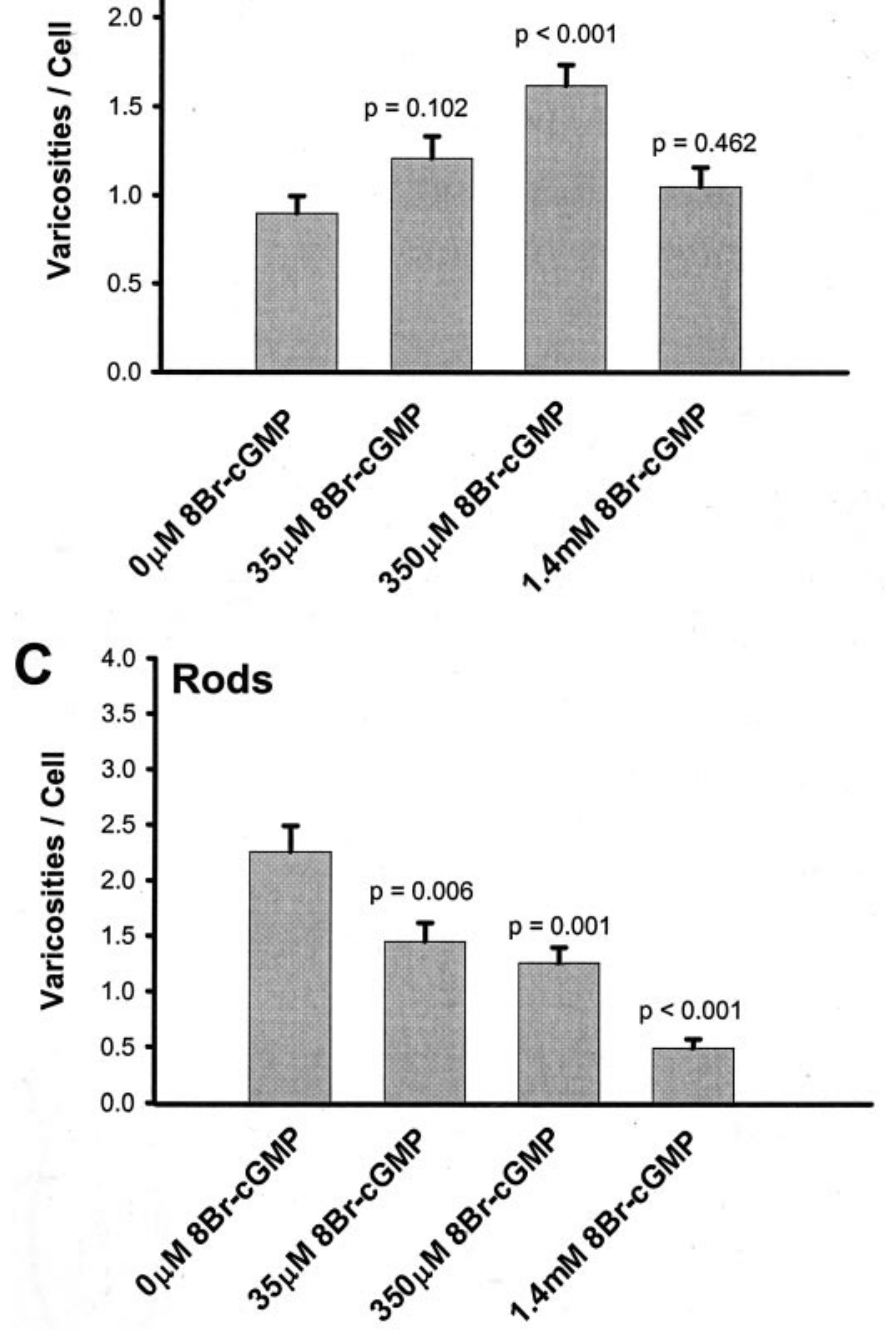

Figure 12. Effect of cGMP-gated channel agonist 8Br-cGMP (an analog of cGMP) on the varicosity formation of photoreceptors. $A$, Experimental design for the administration of 8Br-cGMP. 8Br-cGMP was added to the culture medium immediately after cell plating. $B$, Varicosity formation by cone cells. Varicosities were analyzed with phase-contrast microscopy. $8 \mathrm{Br}-\mathrm{cGMP}$, at $350 \mathrm{~mm}$, caused a significant increase, whereas the other two concentrations caused no significant changes in varicosity formation. $C$, Varicosity formation by rod cells. Anti-opsin-stained varicosities were counted. 8Br-cGMP caused a dose-dependent inhibition of varicosity formation by rod cells. A total of 800 cells in 16 cultures from two animals were analyzed. 
$12 B, C)$. Interestingly, the highest concentration $(1.4 \mathrm{~mm})$ of $8 \mathrm{Br}-\mathrm{cGMP}$ did not further increase the number of varicosities in cone cells (Fig. 12B,C). 8Br-cGMP is also an activator of the protein kinase G family (Surks et al., 1999; Matsunobu and Schacht, 2000), and the activation of this kinase could contribute to an increase or decrease of varicosity development. For instance, it is possible that rod cells are inhibited by protein kinase $\mathrm{G}$ activation. Overall, the data with $8 \mathrm{Br}$-cGMP further supported the hypothesis that $\mathrm{Ca}^{2+}$ influx through cGMPgated channels is essential for the development of presynaptic varicosities in cone cells.

\section{DISCUSSION}

\section{Distinct types of calcium-permeable channels in cone and rod cells are required for structural plasticity and regeneration}

The present study demonstrates that L-type calcium channels in rod cells and cGMP-gated channels in cone cells are the primary calcium channels required for structural plasticity, including regenerative process outgrowth, varicosity formation, and vesicle protein synthesis in salamander photoreceptors. This conclusion is based on the different responses of cone and rod cells to the application of calcium channel antagonists and an agonist.

L-type calcium channels have been found to be essential in the development of neuritic outgrowth in several different neuronal cell types [chick retinal neurons (Suarez-Isla et al., 1984); PC12 cells (Doherty et al., 1991); rat cerebellar, hippocampal, and cortical neurons (Williams et al., 1994, Shitaka et al., 1996, Ramakers et al., 1998)]. This list now includes rod photoreceptors. Our data, however, clearly show that cone cells are less dependent on L-type channel activity for neuritic outgrowth. cGMP-gated channels are widely expressed in the CNS (Wei et al., 1998). The role of cGMP-gated cationic channels in phototransduction in the photoreceptor outer segment has been well established (Yau and Baylor, 1989; Kaupp, 1995), and $\mathrm{Ca}^{2+}$ influx through cGMPgated channels in the inner segments and presynaptic areas of cone cells is known to contribute to neurotransmitter release (Rieke and Schwartz, 1994; Savchenko et al., 1997). Recently, cGMP-gated channels have also been shown to play a role in axonal outgrowth. In olfactory neurons (Kafitz et al., 2000) and snail spinal neurons, activation of guanylyl cyclase leads to filopodial extension as well as an increase of $\left[\mathrm{Ca}^{2+}\right]_{\mathrm{i}}$ (Van Wagenen and Rehder, 1999, 2001). Like these CNS neurons, cone cells have presynaptic growth that can be modulated by a cyclic nucleotide-gated channel. To our knowledge, this is the first report that cone and rod cells require the activity of distinct channels for reactive plasticity. This is also the first demonstration of an agent that can stimulate presynaptic development in adult photoreceptors: $8 \mathrm{Br}-\mathrm{cGMP}$ significantly increased varicosity formation in cone cells. This does not rule out, however, the possibility that L-type calcium channels play some role in cone cell axonal plasticity, especially because branching tertiary processes were significantly reduced in cone cells after nicardipine application.

The use of different calcium-permeable channels in control of axonal activity by cone and rod cells is supported by reports showing that these two photoreceptor types possess many distinct characteristics related to their $\mathrm{Ca}^{2+}$ regulation. Cone and rod cells contain different cGMP-gated cation channels in their outer segments (Wei et al., 1998); in addition, cGMP-gated channels in rod cells, but not in cone cells, may be regulated by $\mathrm{Ca}^{2+}$. calmodulin (Haynes and Stotz, 1997). Caffeine causes transient increases of intracellular $\mathrm{Ca}^{2+}$ concentration $\left(\left[\mathrm{Ca}^{2+}\right]_{\mathrm{i}}\right)$ in salamander rod cells, but no similar $\left[\mathrm{Ca}^{2+}\right]_{\mathrm{i}}$ increase was reported in cone cells (Krizaj et al., 1999). Rod cells do not contain the $\mathrm{Ca}^{2+}$ binding protein calbindin, which is present in cone cells (Pasteels et al., 1990). Finally, the type of L-type channel in rod and cone cells appears to be different. In mammalian retina, cone L-type channels have been reported to contain the $\alpha_{1 \mathrm{D}}$ subunit (Taylor and Morgans, 1998; Morgans, 1999), whereas rod L-type channels contain the $\alpha_{1 \mathrm{~F}}$ subunit (Bech-Hansen et al., 1998; Strom et al., 1998; Morgans, 2001). In salamanders, $\mathrm{Ca}^{2+}$ current profiles reflecting $\alpha_{1 \mathrm{D}}$ subunits in cone cells and $\alpha_{1 \mathrm{~F}}$ subunits in rod cells have been reported (Wilkinson and Barnes, 1996; Kourennyi and Barnes, 2000). Freshly isolated salamander rod cells contained much denser staining by an antibody raised against the $\alpha_{1 \mathrm{C}}$ subunit of L-type calcium channels, than cone cells (NachmanClewner and Townes-Anderson, 1999), and somatostatin reduced voltage-gated L-type $\mathrm{Ca}^{2+}$ current in rod cells but increased this current in cone cells from salamanders (Akopian et al., 2000).

The differences in calcium homeostatic mechanisms between cone and rod cells could contribute to the differential responses that we observed when calcium channel blockers were applied. These differences, however, should not obscure a fundamental difference in the activation mechanisms of the two channel types: membrane potential change for the L-type channels and cGMP concentration for the cyclic nucleotidegated channels. We hypothesize that because of these unique forms of activation, the rod and cone cells react differently to disease at their synaptic terminals. In human retinitis pigmentosa, in animal models of retinal degeneration, and in retinal detachment, rod cell axons and terminals display dramatic structural plasticity but cone cells do not (Li et al., 1995, 1998; Milam et al., 1996; Lewis et al., 1998). It is possible that voltage-gated channels are more easily activated by mechanical perturbation and degenerative disease leading to an increase of $\left[\mathrm{Ca}^{2+}\right]_{i}$ than cGMP-regulated channels. This idea should be amenable to testing in vitro.

\section{Regulation of calcium channels involved in axonal plasticity and regeneration}

Although L-type calcium channels are opened by depolarization, in our experiments photoreceptors were cultured in a medium containing $2.5 \mathrm{~mm} \mathrm{KCl}$, a concentration too low to make global cellular changes in calcium concentration in photoreceptors (Nachman-Clewner and Townes-Anderson, 1999; Uchida and Iuvone, 1999). Nonetheless, the application of L-type calcium channel antagonists inhibited axonal plasticity in rod cells. There are several possible explanations for these results. (1) Although cultured photoreceptors were not intentionally stimulated, the membrane potential of photoreceptors can intrinsically fluctuate, causing $\mathrm{Ca}^{2+}$ influx into cells in minute amounts, enough to activate growth of neuritic structures. In fact, spontaneous, transient depolarizations under basal conditions have been observed in cultured embryonic chicken photoreceptors (Uchida and Iuvone, 1999). (2) Even if there is no fluctuation of membrane potential, it is possible that a small percentage of L-type calcium channels remain in an "active" state, allowing growth-sustaining amounts of $\mathrm{Ca}^{2+}$ into the cells. (3) Mechanisms other than membrane depolarization can regulate the activity of L-type calcium channels. 
$\mathrm{Ca}^{2+}$ transients in growth cone filopodia that can lead to more global elevations of $\left[\mathrm{Ca}^{2+}\right]_{i}$ have been observed using various culture substrates (Kuhn et al., 1998; Gomez et al., 2001). These transients occur in the absence of depolarization and do not involve voltage-gated channels. However, cell adhesion molecules including NCAM, N-cadherin, and L1 have been reported to regulate activities of voltage-gated calcium channels and have been implicated in the regulation of local $\mathrm{Ca}^{2+}$ concentrations during axonal growth (for review, see Doherty et al., 2000). L-type channels are susceptible to this activation. The mechanism involved most likely includes signaling molecules like arachidonic acid (Doherty et al., 2000). It is not clear whether cGMP-gated calcium channels can also be regulated by cell adhesion molecules, but nitric oxide has been shown to promote both calcium influx and filopodial growth in B5 snail neurons, presumably through cGMP-gated channels (Van Wagenen and Rehder, 1999). Additionally, both L-type (for review, see Catterall, 2000) and cGMP-gated channels (Molokanova et al., 1999) can be regulated by phosphorylation. Thus, regulation of calcium influx that is not voltage dependent appears possible and in fact may be common in motile growth cones.

\section{Continuous $\mathrm{Ca}^{2+}$ influx is required for presynaptic development of cultured photoreceptors}

Distinct spatial and temporal patterns of $\mathrm{Ca}^{2+}$ signals are involved in different neuronal activities (De Koninck and Schulman, 1998; Svoboda and Mainen, 1999). For example, only milliseconds are needed for $\mathrm{Ca}^{2+}$ influx to trigger neurotransmitter release from synaptic terminals (Borst and Sakmann, 1996), whereas it takes minutes to hours for some gene expression to be regulated after $\mathrm{Ca}^{2+}$ influx (Hardingham et al., 1997; Tao et al., 1998; Rajadhyaksha et al., 1999). To distinguish between a short-term influx of calcium and a longer-term, perhaps continuous influx as a requirement of structural plasticity in photoreceptors, blockage of L-type calcium channels was delayed by two different time periods ( $1 \mathrm{hr}$ versus $1 \mathrm{~d})$. In both cases, however, process outgrowth in rods was inhibited, suggesting that the process continues to require calcium influx even after $24 \mathrm{hr}$. For the cGMP-gated channels as well, it appears that long-term activity is necessary because $24 \mathrm{hr}$ without blockage was not adequate to support normal presynaptic growth. These data, however, do not distinguish which part of the process, gene regulation, protein synthesis, anterograde transport, vesicle exocytosis, or cytoskeletal turnover, continues to be $\mathrm{Ca}^{2+}$ dependent.

\section{The synthesis of vesicle proteins requires $\mathrm{Ca}^{2+}$ influx}

Blockage of L-type calcium channels in rod cells and cGMPgated channels in cone cells not only inhibited presynaptic plasticity but also significantly inhibited the synthesis of vesicle proteins as measured by the presence of protein in the TGNs. Normally, an increase in vesicle protein synthesis occurs after 24-48 hr in culture (Nachman-Clewner and TownesAnderson, 1996; Zhang and Townes-Anderson, unpublished observations), suggesting that gene regulation is involved. Calcium has been known to participate in gene regulation since the 1980 s when the opening of L-type voltage-gated calcium channels by membrane depolarization of PC12 cells was reported to induce expression of $c$-fos, an immediate early gene (Greenberg et al., 1986; Morgan and Curran, 1986). The $\mathrm{Ca}^{2+}$ - dependent signaling pathways in cone and rod cells that might regulate the synthesis of vesicle proteins remain to be discovered. However, it is known that mRNA levels for melatonin $\mathrm{N}$-transferase are regulated by $\mathrm{Ca}^{2+}$ influx via cAMP (Gan et al., 1995; Gréve et al., 1999). It is possible that a similar mechanism may be involved in the regulation of genes such as those for synaptic vesicle proteins necessary for plasticity and regeneration. Future in situ hybridization experiments on vesicle protein mRNA will help differentiate between the effects of $\mathrm{Ca}^{2+}$ influx on gene transcription and mRNA translation.

\section{REFERENCES}

Akopian A, Johnson J, Gabriel R, Brecha N, Witkovsky P (2000) Somatostatin modulates voltage-gated $\mathrm{K}^{+}$and $\mathrm{Ca}^{2+}$ currents in rod and cone photoreceptors of the salamander retina. J Neurosci 20:929-936.

Antony C, Cibert C, Géraud G, Santa Maria A, Maro B, Mayau V, Goud B (1992) The small GTP-binding protein rab6 is distributed from medial Golgi to the trans-Golgi network as determined by a confocal microscopic approach. J Cell Sci 103:785-796.

Bech-Hansen NT, Naylor MJ, Maybaum TA, Pearce WG, Koop B, Fishman GA, Mets M, Musarella MA, Boycott KM (1998) Loss-offunction mutations in a calcium-channel $\alpha_{1}$-subunit gene in Xp11.23 cause incomplete $\mathrm{X}$-linked congenital stationary night blindness. Nat Genet 19:264-267

Benfey M, Búnger UR, Vidal-Sanz M, Bray GM, Aguayo AJ (1985) Axonal regeneration from GABAergic neurons in the adult rat thalamus. J Neurocytol 14:279-296.

Borst JGG, Sakmann B (1996) Calcium influx and transmitter release in a fast CNS synapse. Nature 383:431-434.

Buckley K, Kelly RB (1985) Identification of a transmembrane glycoprotein specific for secretory vesicles of neural and endocrine cells. J Cell Biol 100:1284-1294.

Catterall WA (2000) Structure and regulation of voltage-gated $\mathrm{Ca}^{2+}$ channels. Annu Rev Cell Dev Biol 16:521-555.

Chong NHV, Alexander RA, Barnett KC, Bird AC, Luthert PJ (1999) An immunohistochemical study of autosomal dominant feline rod/cone dysplasia (Rdy cats). Exp Eye Res 68:51-57.

Cobbs WH, Barkdoll AE III, Pugh EN Jr (1985) Cyclic GMP increases photocurrent and light sensitivity of retinal cones. Nature 317:64-66.

De Koninck P, Schulman H (1998) Sensitivity of CaM kinase II to the frequency of $\mathrm{Ca}^{2+}$ oscillations. Science 279:227-230.

Deretic D, Papermaster DS (1993) Rab6 is associated with a compartment that transports rhodopsin from the trans-Golgi to the site of rod outer segment disk formation in frog retinal photoreceptors. J Cell Sci 106:803-813.

Doherty P, Ashton SV, Moore SE, Walsh FS (1991) Morphoregulatory activities of NCAM and N-cadherin can be accounted for by $G$ proteindependent activation of $\mathrm{L}$ - and $\mathrm{N}$-type neuronal $\mathrm{Ca}^{2+}$ channels. Cell 67:21-33.

Doherty P, Williams G, Williams EJ (2000) CAMs and axonal growth: a critical evaluation of the role of calcium and the MAPK cascade. Mol Cell Neurosci 16:283-295.

Erickson PA, Fisher SK, Anderson DH, Stern WH, Borgula GA (1983) Retinal detachment in the cat: the outer nuclear and outer plexiform layers. Invest Ophthalmol Vis Sci 24:927-942.

Gan J, Alonso-Gómez AL, Avendano G, Johnson B, Iuvone PM (1995) Melatonin biosynthesis in photoreceptor-enriched chick retinal cell cultures: role of cyclic AMP in the $\mathrm{K}^{+}$-evoked, $\mathrm{Ca}^{2+}$-dependent induction of serotonin $N$-acetyltransferase activity. Neurochem Int 27:147-155.

Gomez TM, Robles E, Poo M-M, Spitzer NC (2001) Filopodial calcium transients promote substrate-dependent growth cone turning. Science 291:1983-1987.

Goud B, Zahraoui A, Tavitian A, Saraste J (1990) Small GTP-binding protein associated with Golgi cisternae. Nature 345:553-556.

Greenberg ME, Ziff EB, Greene LA (1986) Stimulation of neuronal acetylcholine receptors induces rapid gene transcription. Science 234:80-83.

Gréve P, Alonso-Gómez A, Bernard M, Ma M, Haque R, Klein DC, Iuvone PM (1999) Serotonin N-acetyltransferase mRNA levels in photoreceptor-enriched chicken retinal cell cultures: elevation by cyclic AMP. J Neurochem 73:1894-1900.

Hannah MJ, Schmidt AA, Huttner WB (1999) Synaptic vesicle biogenesis. Annu Rev Cell Dev Biol 15:733-798.

Harding J, Graziadei PPC, Monti Graziadei GA, Margolis FL (1977) Denervation in the primary olfactory pathway of mice. IV. Biochemical 
and morphological evidence for neuronal replacement following nerve section. Brain Res 132:11-28.

Hardingham GE, Chawla S, Johnson CM, Bading H (1997) Distinct functions of nuclear and cytoplasmic calcium in the control of gene expression. Nature 385:260-265.

Haynes LW, Stotz SC (1997) Modulation of rod, but not cone, cGMPgated photoreceptor channels by calcium-calmodulin. Vis Neurosci 14:233-239.

Hicks D, Molday RS (1986) Differential immunogold-dextran labeling of bovine and frog rod and cone cells using monoclonal antibodies against bovine rhodopsin. Exp Eye Res 42:55-71.

Hille B (1992) Ionic channels of excitable membranes, Ed 2. Sunderland, MA: Sinauer.

Hockerman GH, Johnson BD, Abbott MR, Scheuer T, Catterall WA (1997a) Molecular determinants of high affinity phenylalkylamine block of L-type calcium channels in transmembrane segment IIIS6 and the pore region of the $\alpha_{1}$ subunit. J Biol Chem 272:18759-18765.

Hockerman GH, Peterson BZ, Johnson BD, Catterall WA (1997b) Molecular determinants of drug binding and action on L-type calcium channels. Annu Rev Pharmacol Toxicol 37:361-396.

Ikeda S, Oka J-I, Nagano T (1991) Effects of four diltiazem stereoisomers on binding of D-cis- $\left[{ }^{3} \mathrm{H}\right]$ diltiazem and $(+)-\left[{ }^{3} \mathrm{H}\right] \mathrm{PN} 200-110$ to rabbit T-tubule calcium channels. Eur J Pharmacol 208:199-205.

Jansen HG, Sanyal S (1984) Development and degeneration of retina in $r d s$ mutant mice: electron microscopy. J Comp Neurol 224:71-84.

Jansen HG, Sanyal S (1987) Synaptic changes in the terminals of rod photoreceptors of albino mice after partial visual cell loss induced by brief exposure to constant light. Cell Tissue Res 250:43-52.

Jansen HG, Sanyal S (1992) Synaptic plasticity in the rod terminals after partial photoreceptor cell loss in the heterozygous $r d s$ mutant mouse. J Comp Neurol 316:117-125.

Kafitz KW, Leinders-Zufall T, Zufall F, Greer CA (2000) Cyclic GMP evoked calcium transients in olfactory receptor cell growth cones. NeuroReport 11:677-681.

Kaupp UB (1995) Family of cyclic nucleotide gated ion channels. Curr Opin Neurobiol 5:434-442.

Kourennyi DE, Barnes S (2000) Depolarization-induced calcium channel facilitation in rod photoreceptors is independent of $\mathrm{G}$ proteins and phosphorylation. J Neurophysiol 84:133-138.

Krizaj D, Bao J-X, Schmitz Y, Witkovsky P, Copenhagen DR (1999) Caffeine-sensitive calcium stores regulate synaptic transmission from retinal rod photoreceptors. J Neurosci 19:7249-7261.

Kuhn TB, Williams CV, Dou P, Kater SB (1998) Laminin directs growth cone navigation via two temporally and functionally distinct calcium signals. J Neurosci 18:184-194.

Kurenny DE, Moroz LL, Turner RW, Sharkey KA, Barnes S (1994) Modulation of ion channels in rod photoreceptors by nitric oxide. Neuron 13:315-324.

Lewis GP, Linberg KA, Fisher SK (1998) Neurite outgrowth from bipolar and horizontal cells after experimental retinal detachment. Invest Ophthalmol Vis Sci 39:424-434.

Li Z-Y, Kljavin IJ, Milam AH (1995) Rod photoreceptor neurite sprouting in retinitis pigmentosa. J Neurosci 15:5429-5438.

Li Z-Y, Wong F, Chang JH, Possin DE, Hao Y, Petters RM, Milam AH (1998) Rhodopsin transgenic pigs as a model for human retinitis pigmentosa. Invest Opthalmol Vis Sci 39:808-819.

Lyon MJ, Stelzner DJ (1987) Tests of the regenerative capacity of tectal efferent axons in the frog, Rana pipiens. J Comp Neurol 255:511-525.

MacLeish PR, Townes-Anderson E (1988) Growth and synapse formation among major classes of adult salamander retinal neurons in vitro. Neuron 1:751-760.

MacLeish PR, Barnstable CJ, Townes-Anderson E (1983) Use of a monoclonal antibody as a substrate for mature neurons in vitro. Proc Natl Acad Sci USA 80:7014-7018.

Mandell JW, MacLeish PR, Townes-Anderson E (1993) Process outgrowth and synaptic varicosity formation by adult photoreceptors in vitro. J Neurosci 13:3533-3548.

Matsunobu T, Schacht J (2000) Nitric oxide/cyclic GMP pathway attenuates ATP-evoked intracellular calcium increase in supporting cells of the guinea pig cochlea. J Comp Neurol 423:452-461.

Milam AH, Li Z-Y, Ciderciyan AV, Jacobson SG (1996) Clinicopathologic effects of the Q64ter rhodopsin mutation in retinitis pigmentosa. Invest Ophthalmol Vis Sci 37:753-765.

Molokanova E, Maddox F, Luetje CW, Kramer RH (1999) Activitydependent modulation of rod photoreceptor cyclic nucleotide-gated channels mediated by phosphorylation of a specific tyrosine residue. J Neurosci 19:4786-4795.

Morgan JI, Curran T (1986) The role of ion flux in the control of $c$-fos expression. Nature 322:552-555.

Morgans CW (1999) Calcium channel heterogeneity among cone populations in tree shrew retina. Eur J Neurosci 11:2989-2993.
Morgans CW (2001) Localization of the $\alpha_{1 \mathrm{~F}}$ calcium channel subunit in the rat retina. Invest Ophthalmol Vis Sci 42:2414-2418.

Nachman-Clewner M, Townes-Anderson E (1996) Injury-induced remodelling and regeneration of the ribbon presynaptic terminal in vitro. J Neurocytol 25:597-613.

Nachman-Clewner M, Townes-Anderson E (1999) L-type calcium channels in the photoreceptor ribbon synapse: localization and role in plasticity. J Comp Neurol 415:1-16.

Pasteels B, Rogers J, Blachier F, Pochet R (1990) Calbindin and calretinin localization in retina from different species. Vis Neurosci 5:1-6.

Peng YW, Hao Y, Petters RM, Wong F (2000) Ectopic synaptogenesis in the mammalian retina caused by rod photoreceptor-specific mutations. Nat Neurosci 3:1121-1127.

Peterson BZ, Johnson BD, Hockerman GH, Acheson M, Scheuer T, Catterall WA (1997) Analysis of the dihydropyridine receptor site of L-type calcium channels by alanine-scanning mutagenesis. J Biol Chem 272:18752-18758.

Quandt FN, Nicol GD, Schnetkamp PPM (1991) Voltage-dependent gating and block of the cyclic-GMP-dependent current in bovine rod outer segments. Neuroscience 42:629-638.

Raisman G (1969) Neuronal plasticity in the septal nuclei of the adult rat. Brain Res 14:25-48.

Rajadhyaksha A, Barczak A, Macías W, Leveque J-C, Lewis SE, Konradi C (1999) L-type $\mathrm{Ca}^{2+}$ channels are essential for glutamate-mediated CREB phosphorylation and $c$-fos gene expression in striatal neurons. J Neurosci 19:6348-6359.

Ramakers GJA, Winter J, Hoogland TM, Lequin MB, van Hulten P, van Pelt J, Pool CW (1998) Depolarization stimulates lamellipodia formation and axonal but not dendritic branching in cultured rat cerebral cortex neurons. Dev Brain Res 108:205-216.

Rebrik TI, Korenbrot JI (1998) In intact cone photoreceptors, a $\mathrm{Ca}^{2+}$. dependent, diffusible factor modulates the cGMP-gated ion channels differently than in rods. J Gen Physiol 112:537-548.

Rieke F, Schwartz EA (1994) A cGMP-gated current can control exocytosis at cone synapses. Neuron 13:863-873.

Savchenko A, Barnes S, Kramer RH (1997) Cyclic-nucleotide-gated channels mediate synaptic feedback by nitric oxide. Nature 390:694-698.

Sherry DM, Bui DD, DeGrip WJ (1998) Identification and distribution of photoreceptor subtypes in the neotenic tiger salamander retina. Vis Neurosci 15:1175-1187.

Shitaka Y, Matsuki N, Saito H, Katsuki H (1996) Basic fibroblast growth factor increases functional L-type $\mathrm{Ca}^{2+}$ channels in fetal rat hippocampal neurons: implications for neurite morphogenesis in vitro. J Neurosci 16:6476-6487.

Stern JH, Kaupp UB, MacLeish PR (1986) Control of the lightregulated current in rod photoreceptors by cyclic GMP, calcium, and L-cis-diltiazem. Proc Natl Acad Sci USA 83:1163-1167.

Strom TM, Nyakatura G, Apfelstedt-Sylla E, Hellebrand H, Lorenz B, Weber BHF, Wutz K, Gutwillinger N, Rüther K, Drescher B, Sauer C, Zrenner E, Meitinger T, Rosenthal A, Meindl A (1998) An L-type calcium-channel gene mutated in incomplete X-linked congenital stationary night blindness. Nat Genet 19:260-263.

Suarez-Isla BA, Pelto DJ, Thompson JM, Rapoport SI (1984) Blockers of calcium permeability inhibit neurite extension and formation of neuromuscular synapses in cell culture. Dev Brain Res 14:263-270.

Surks HK, Mochizuki N, Kasai Y, Georgescu SP, Tang KM, Ito M, Lincoln TM, Mendelsohn ME (1999) Regulation of myosin phosphatase by a specific interaction with cGMP-dependent protein kinase I $\alpha$. Science 286:1583-1587.

Svoboda K, Mainen ZF (1999) Synaptic $\left[\mathrm{Ca}^{2+}\right]$ : intracellular stores spill their guts. Neuron 22:427-430.

Tao X, Finkbeiner S, Arnold DB, Shaywitz AJ, Greenberg ME (1998) $\mathrm{Ca}^{2+}$ influx regulates $B D N F$ transcription by a CREB family transcription factor-dependent mechanism. Neuron 20:709-726.

Taylor WR, Morgans CW (1998) Localization and properties of voltagegated calcium channels in cone photoreceptors of Tupaia belangeri. Vis Neurosci 15:541-552.

Townes-Anderson E, Nachman-Clewner M (2001) Axonal and synaptic regeneration by salamander photoreceptors. In: Axonal regeneration in the central nervous system (Ingoglia NA, Murray M, eds). pp 107-127. New York: Marcel Dekker.

Uchida K, Iuvone PM (1999) Intracellular $\mathrm{Ca}^{2+}$ concentrations in cultured chicken photoreceptor cells: sustained elevation in depolarized cells and the role of dihydropyridine-sensitive $\mathrm{Ca}^{2+}$ channels. Mol Vis 5:1-8.

Valtorta F, Jahn R, Fesce R, Greengard P, Ceccarelli B (1988) Synaptophysin (p38) at the frog neuromuscular junction: its incorporation into the axolemma and recycling after intense quantal secretion. J Cell Biol 107:2717-2727.

Van Wagenen S, Rehder V (1999) Regulation of neuronal growth cone filopodia by nitric oxide. J Neurobiol 39:168-185. 
Van Wagenen S, Rehder V (2001) Regulation of neuronal cone filopodia by nitric oxide depends on soluble guanylyl cyclase. J Neurobiol 46:206-219.

Wei J-Y, Roy DS, Leconte L, Barnstable CJ (1998) Molecular and pharmacological analysis of cyclic nucleotide-gated channel function in the central nervous system. Prog Neurobiol 56:37-64.

Wilkinson MF, Barnes S (1996) The dihydropyridine-sensitive calcium channel subtype in cone photoreceptors. J Gen Physiol 107:621-630.

Williams EJ, Walsh FS, Doherty P (1994) The production of arachidonic acid can account for calcium channel activation in the second messenger pathway underlying neurite outgrowth stimulated by NCAM, $\mathrm{N}$-cadherin, and L1. J Neurochem 62:1231-1234.

Xiong W-H, Solessio EC, Yau KW (1998) An unusual cGMP pathway underlying depolarizing light response of the vertebrate parietal-eye photoreceptor. Nat Neurosci 1:359-365.

Yau KW, Baylor DA (1989) Cyclic GMP-activated conductance of retinal photoreceptor cells. Annu Rev Neurosci 12:289-327.

Zhang N, Townes-Anderson E (2000) Delayed blockage of L-type $\mathrm{Ca}^{2+}$ channels with nicardipine inhibits presynaptic plasticity of photoreceptors in vitro. Invest Ophthalmol Vis Sci 41:S596.

Zhang N, Townes-Anderson E (2001) Blockage of cGMP-gated channels inhibits varicosity formation and vesicle protein synthesis by salamander cone cells in vitro. Invest Ophthalmol Vis Sci 42:S365.

Zimmerman AL (1995) Cyclic nucleotide gated channels. Curr Opin Neurobiol 5:296-303. 